\title{
RESEARCH
}

Open Access

\section{TNFa/TNFR2 signaling pathway: an active immune checkpoint for mesenchymal stem cell immunoregulatory function}

\author{
Ghada Beldi ${ }^{1,3}$, Maryam Khosravi ${ }^{4}$, Mohamed Essameldin Abdelgawad ${ }^{1,5}$, Benoît L. Salomon ${ }^{4}$, Georges Uzan ${ }^{1,2}$, \\ Houda Haouas $^{3 * \dagger}$ and Sina Naserian ${ }^{1,2,6^{*}+}$ (i)
}

\begin{abstract}
Background: In addition to their multilineage potential, mesenchymal stem cells (MSCs) have a broad range of functions from tissue regeneration to immunomodulation. MSCs have the ability to modulate the immune response and change the progression of different inflammatory and autoimmune disorders. However, there are still many challenges to overcome before their widespread clinical administration including the mechanisms behind their immunoregulatory function. MSCs inhibit effector T cells and other immune cells, while inducing regulatory $T$ cells (T regs), thus, reducing directly and indirectly the production of pro-inflammatory cytokines. TNF/TNFR signaling plays a dual role: while the interaction of TNFa with TNFR1 mediates pro-inflammatory effects and cell death, its interaction with TNFR2 mediates anti-inflammatory effects and cell survival. Many immunosuppressive cells like T regs, regulatory B cells (B regs), endothelial progenitor cells (EPCs), and myeloid-derived suppressor cells (MDSCs) express TNFR2, and this is directly related to their immunosuppression efficiency. In this article, we investigated the role of the TNFa/TNFR2 immune checkpoint signaling pathway in the immunomodulatory capacities of MSCs.

Methods: Co-cultures of MSCs from wild-type (WT) and TNFR2 knocked-out (TNFR2 KO) mice with T cells (WT and TNFa $\mathrm{KO}$ ) were performed under various experimental conditions.

Results: We demonstrate that TNFR2 is a key regulatory molecule which is strongly involved in the immunomodulatory properties of MSCs. This includes their ability to suppress T cell proliferation, activation, and pro-inflammatory cytokine production, in addition to their capacity to induce active T regs.

Conclusions: Our results reveal for the first time the importance of the TNFa/TNFR2 axis as an active immune checkpoint regulating MSC immunological functions.
\end{abstract}

Keywords: Mesenchymal stem cells, Immune regulation, Tolerance induction, Regulatory T cells, TNFa/TNFR2 signaling pathway, Immune checkpoint

\footnotetext{
*Correspondence: haouas_houda@insat.rnu.tn; haouas_h@yahoo.com;

sina.naserian@inserm.fr; sina.naserian@cellmedex.com;

sina.naserian@gmail.com

Houda Haouas and Sina Naserian are equally co-last authors

${ }^{3}$ National Institute of Applied Sciences and Technology (INSAT), Carthage

University, LR18ES40, Inflammation, environment and signalization

pathologies, Tunis, Tunisia

${ }^{1}$ INSERM UMR-S-MD 1197, Hôpital Paul Brousse, Villejuif, France

Full list of author information is available at the end of the article
}

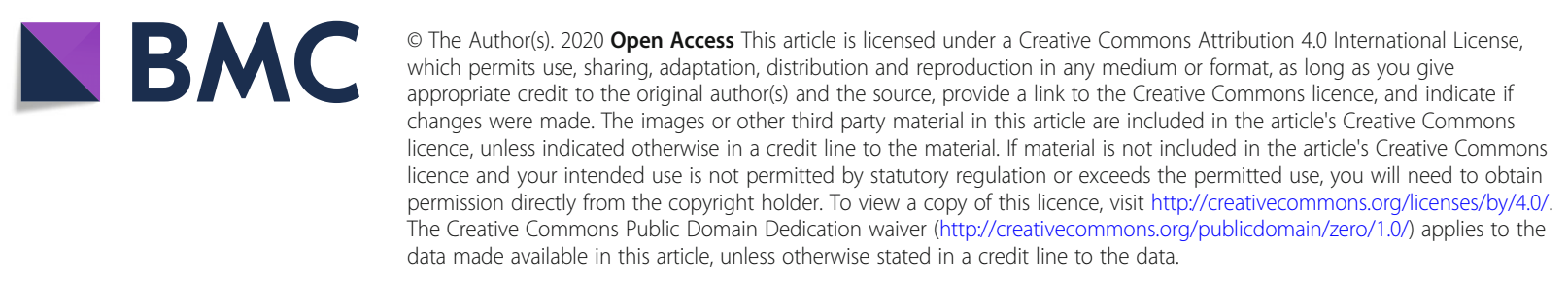




\section{Background}

MSCs represent heterogeneous population of nonhematopoietic [1], fibroblast-like multipotent stem cells [2-4]. Unlike many other stem cells that are tissuespecific, MSCs are present in various tissues, including bone marrow (BM), adipose tissue, amniotic fluid, endometrium, dental tissues, umbilical cord [2], and many others [5] in different species from mice to human [6].

MSCs are self-renewable, easily accessible, spindleshaped cells that are expandable in vitro and show exceptional genomic stability $[2,7]$. Their "stemness" is exemplified by their ability to differentiate, under certain physiological and experimental conditions [8], into multiple mesoderm cell types, including osteocytes, chondrocytes, adipocytes, and smooth muscle cells [9-11]. They can also differentiate into cell types of other germ layers, like neurons (ectoderm) and hepatocytes (endoderm) $[9,12,13]$.

To identify MSCs in a mixed population of cells, the International Society for Cellular Therapy has proposed minimum criteria: adherence to plastic; expression of CD73, CD90, and CD105 markers; and the absence of the expression of CD14, CD34, CD45, HLA-DR monocyte, and hematopoietic markers [3, 6, 14, 15]. Moreover, they can express CD44 [1] and Sca1 (murine MSCs) markers [15]. Indeed, there are some interspecies differences regarding the expression of different mentioned markers. For example, CD105 and CD90 are strongly expressed on the majority of species including murine MSCs but are low on goat and sheep MSCs [16]. Finally, they must be able to differentiate in vitro into mesoderm cell types [17].

During the last decade, MSCs have drawn much attention for their application in regenerative medicine $[18,19]$. This is mainly due to the fact that, among multipotent stem cells, uniquely MSCs can differentiate into different cell types from the three germ layers, to produce soluble growth factors and cytokines [20] and to maintain tissues homeostasis by replacing dead or dysfunctional cells [21]. Furthermore, some studies revealed that MSCs can stimulate resident cells and promote tissue regeneration [22].

Likewise, MSCs have generated considerable interest for exerting immunomodulatory functions. Several in vitro and in vivo studies indicated that MSCs strongly suppress immune cells in innate and adaptive immune systems [23, 24]. MSCs inhibit effector $\mathrm{T}$ cell proliferation and function in both autologous and allogenic conditions while activating and inducing $\mathrm{T}$ regs [25-27]. Consequently, they reduce pro-inflammatory cytokine production, including tumor necrosis factor alpha (TNF $\alpha)$ [8].

TNF $\alpha$ binds to two structurally distinct receptors, TNFR1 and TNFR2. TNFR1 is expressed ubiquitously, and its interaction with TNF $\alpha$ leads to apoptosis and cell death. Inversely, TNFR2 is expressed on limited cells, namely immune cells, endothelial cells, neural cells, and MSCs. Its interaction with TNF $\alpha$ leads to cell survival and proliferation $[9,28,29]$. Previous studies revealed that the TNF $\alpha /$ TNFR2 signaling in MSCs supports proangiogenic and protective mechanisms, and inversely, the TNF $\alpha /$ TNFR1 axis is involved in deleterious mechanisms. For example, murine TNFR2 KO bone marrow MSCs (BM-MSCs) showed less or no myocardial functional recovery in a rat model of acute ischemia accompanied by increased production of pro-inflammatory factors and reduced level of VEGF in the myocardium $[30,31]$. This is consistent with other studies demonstrating that the production of VEGF, insulin-like growth factor 1 (IGF-1), and hepatocyte growth factor (HGF) by TNF-primed human BM-MSCs is TNFR2dependent [32, 33]. Furthermore, the overexpression of the soluble form of TNFR2 (sTNFR2) or the membrane form of TNFR2 in human or rat BM-MSCs enhanced their therapeutic effects in murine models of RA [34, 35] and cardiac ischemia [36, 37], which was associated with reduced TNF, IL-1 $\beta$, and IL- 6 secretion.

Interestingly, many immunosuppressive cells like $\mathrm{T}$ regs, MDSCs, B regs, and EPCs express TNFR2 which is directly related to their immunosuppressive efficiency mostly through modulating the secretion of antiinflammatory cytokines [38-41]. MSCs are susceptible to environmental changes, and their immunosuppressive function can be regulated when exposed to an inflammatory microenvironment [42]. The presence of TNF $\alpha$ and other pro-inflammatory cytokines prime MSCs towards more immunosuppressive functions [43-47].

To investigate the involvement of the TNF $\alpha / T N F R 2$ signaling pathway in the immunoregulatory effect of MSCs, we considered the following facts: (1) MSCs are among the rare population of TNFR $2^{+}$cells, and TNF $\alpha$ is important for their activation and immunomodulatory effect. (2) Many immunosuppressive cells express TNFR2 which is directly related to their immunosuppressive efficiency. Thus, we investigated if the expression of TNFR2 by MSCs is related to their proper immunoregulatory activities. We harvested BM-MSCs from TNFR2 KO mice and compared them with WT-MSCs expressing normal levels of TNFR2. Our results demonstrate for the first time that the TNF $\alpha$ /TNFR2 signaling pathway plays a critical role in the immunomodulatory effect of MSCs directly through higher suppression of $\mathrm{T}$ cells and indirectly via induction of more phenotypically active Foxp $3^{+} \mathrm{T}$ regs.

\section{Methods}

\section{MSC isolation, expansion, and characterization}

BM-MSCs were isolated from the femurs and tibias of 6- to 8-week-old C57BL/6 WT mice (Charles River and Envigo) and C57BL/6 TNFR2 KO (B6.129S2-Tnfrsf1b ${ }^{\mathrm{tm} 1 \mathrm{Mwm}} / \mathrm{J}$, The Jackson Laboratory). Mice were housed under 
pathogen-free conditions. Cells were cultured in $25-\mathrm{cm}^{2}$ flasks in MEM $\alpha$ medium (Gibco) containing low glucose, 1\% GlutaMAX, 10\% FBS, and 1\% penicillin/streptomycin/ neomycin $(\mathrm{P} / \mathrm{S} / \mathrm{N})(\mathrm{Gibco})$. Cells were incubated at $37^{\circ} \mathrm{C}$ in a $5 \% \mathrm{CO}_{2}$. Non-adherent cells were removed every $8 \mathrm{~h}$; pure MSCs were obtained after 4-5 weeks. Cells were subcultured prior to confluency. In all experiments, WT and TNFR2 KO MSCs were used in passages 2 to 4.

For the identification of MSCs, $10^{5}$ cells/well WT and TNFR2-MSCs were seeded in Falcon 96-well roundbottom plates. They were then immunostained with CD44-PeCy7, Sca1-APC, CD105-FITC, CD73-PE, CD45VIOBLUE, CD34-Biotin or FITC, CD90-Biotin or PE and anti-biotin-PE or VIOBLUE (Miltenyi), and streptavidin$\mathrm{PeCY} 5 / \mathrm{CY} 7$ (eBioscience). Unstained cells and isotypes were used as controls. Flow cytometric analysis was performed using the LSRFORTESSA flow cytometer (BDBiosciences) and analyzed using the FlowJo software v10 (FlowJo-LLC).

\section{MSC differentiation assay}

WT and TNFR2 KO-MSCs were tested for their ability to differentiate into adipocytes and osteoblasts. Adipogenic differentiation was induced by culturing cells in a specific differentiation homemade medium for 21 days as already described [48]. Cells were then stained with Oil Red for $5 \mathrm{~min}$. For osteocyte differentiation, MSCs were cultured in differentiation medium (StemXVIVO Osteogenic/Adipogenic Base Media supplemented with $\mathrm{P} / \mathrm{S} / \mathrm{N}$ at 1:100 dilution + StemXVIVO Mouse/Rat Osteogenic Supplement 20x) (R\&D Systems) for 17 days and stained 3 min with $2 \%$ Alizarin Red.

\section{T cell isolation and culture}

Pan T cell isolation kit II (Miltenyi) was used to isolate total $\mathrm{CD}^{+} \mathrm{T}$ cells from pooled spleens and lymph nodes of 6- to 12-weeks-old female WT C57BL/6 mice (Envigo and Charles River) and TNF $\alpha$ KO mice (B6.129S-

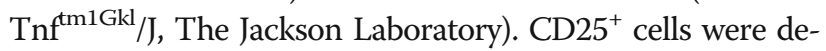
pleted from the $\mathrm{CD}^{+} \mathrm{T}$ cell population using an anti-CD25 biotin-conjugated antibody (7D4, BD-biosciences), followed by staining with anti-biotin microbeads (Miltenyi). Subsequently, cells were isolated using magnetic-activated cell sorting (MACS). The resulting $\mathrm{CD}^{+} \mathrm{CD} 25^{-} \mathrm{T}$ cells, $\geq 92 \%$ pure, were cultured in the presence of WT and TNFR2 KO-MSCs.

\section{$\mathrm{MSC} / \mathrm{T}$ cell co-culture}

WT or TNFR2 KO-MSCs were seeded into 6-well or 12-well plates and incubated for $24 \mathrm{~h}$ in MEM $\alpha$ containing low glucose, $1 \%$ GlutaMAX, $10 \% \mathrm{FBS}$, and $1 \% \mathrm{P} / \mathrm{S} / \mathrm{N}$ (Gibco). $\mathrm{CD}^{+} \mathrm{CD} 25^{-} \mathrm{T}$ cells were then added in different ratios, depending on experimental conditions, in RPMI medium containing $10 \% \mathrm{FBS}, 1 \% \mathrm{P} / \mathrm{S} / \mathrm{N}, 1 \%$ HEPES, and
$0.1 \% \beta$-mercaptoethanol. All co-cultures were performed in 50\% MEM $\alpha-50 \%$ RMPI media. T cells were collected after 3 days by gentle aspiration. The isolation of $\mathrm{T}$ cells from co-culture is based on MSCs' ability to adhere to plastic; however, $\mathrm{T}$ cells stay in suspension.

\section{T lymphocyte proliferation assay}

$5 \times 10^{4}$ WT or TNFR2 KO-MSCs were co-cultured in 6well plates with increasing numbers of mice WT$\mathrm{CD}^{+} \mathrm{CD} 25^{-} \mathrm{T}$ cells (responder cells) in a total volume of $3 \mathrm{ml}$. The ratios of MSCs to T cells were $1 / 1,1 / 2,1 / 4,1 /$ 6, $1 / 8$, and $1 / 10.2 \times 10^{5}$ WT $\mathrm{CD}^{+} \mathrm{CD} 25^{-} \mathrm{T}$ cells were used as control $\mathrm{T}$ cells alone. Cells were labeled with carboxy fluorescein succinimidyl ester (CFSE) (Thermo Fisher) and stimulated by Dynabeads Mouse T-Activator CD3/CD28 (Gibco) according to the supplier's protocol. After 3 days, $\mathrm{T}$ cells were collected and immunostained with CD4-VIOBLUE and CD8 $\alpha$-PeCy7 (Miltenyi). To eliminate the possibility of a non-specific effect of media on $\mathrm{T}$ cell proliferation, $\mathrm{T}$ cells were cultured in $50 \%$ RPMI-50\% MEM $\alpha$ and compared to growth in 100\% RPMI.

\section{T lymphocytes activation quantification}

$3 \times 10^{4}$ WT or TNFR2 KO-MSCs were co-cultured in 12-well plates with $1.5 \times 10^{5}$ (1/5 ratio) of mice WT$\mathrm{CD}^{+} \mathrm{CD} 25^{-} \mathrm{T}$ cells in a total volume of $2 \mathrm{ml}$. We used this intermediate fixed ratio since we observed $50 \%$ immunosuppressive activity by MSCs. WT-CD ${ }^{+} \mathrm{CD} 25^{-} \mathrm{T}$ cells were stimulated by Dynabeads Mouse T-Activator CD3/CD28 (Gibco). $2 \times 10^{5}$ freshly isolated WT$\mathrm{CD}^{+} \mathrm{CD} 25^{-} \mathrm{T}$ cells were used as control $\mathrm{T}$ cells alone. After 3 days, WT-CD ${ }^{+} \mathrm{CD} 25^{-} \mathrm{T}$ cells were harvested and immunostained with CD4-VIOBLUE and CD8 $\alpha$ PeCy5 or CD8 $\alpha$-FITC, ICOS-PeCy7, GITR-PE, CD25PeCy7 or PE, and TNFR2-APC (Miltenyi). Intracellular Foxp3 staining was performed according to the manufacturer's instructions, using the Foxp3 staining buffer set kit (eBioscience).

\section{T lymphocyte cytokine quantification}

$3 \times 10^{4}$ WT or TNFR2 KO-MSCs were co-cultured in 12-well plates with $1.5 \times 10^{5}$ (1/5 ratio) of fresh mice WT CD $3^{+} \mathrm{CD} 25^{-} \mathrm{T}$ cells in a total volume of $2 \mathrm{ml}$. After 3 days, WT-CD $3^{+} \mathrm{CD} 25^{-} \mathrm{T}$ cells were harvested. Cells were then stimulated with $1 \mu \mathrm{g} / \mathrm{ml}$ PMA and $0.5 \mu \mathrm{g} / \mathrm{ml}$ ionomycin for $4 \mathrm{~h}$ and $30 \mathrm{~min}$ (Sigma), in the presence of $1 \mu \mathrm{l} / \mathrm{ml}$ GolgiPlug for the last hour (BD Biosciences). They were then immunostained with CD4-VIOBLUE, CD8 $\alpha$ - Pe-Cy7, IFN $\gamma$-APC, TNF $\alpha$-FITC, IL-10-APC, IL17-PE, IL-2-FITC (Miltenyi), and anti-TGF $\beta$-PE (Biolegend). 


\section{$T$ reg induction assay}

$3 \times 10^{4}$ WT or TNFR2 KO-MSCs were co-cultured in 12-well plates with increasing numbers of mice WT$\mathrm{CD}^{+} \mathrm{CD} 25^{-} \mathrm{T}$ cells in a total volume of $2 \mathrm{ml}$. The ratios of MSCs to T cells were $1 / 1,1 / 2,1 / 4,1 / 6,1 / 8$, and $1 / 10$. $2 \times 10^{5}$ WT-CD ${ }^{+} \mathrm{CD} 25^{-} \mathrm{T}$ cells were used as control $\mathrm{T}$ cells alone. $\mathrm{T}$ cells were stimulated with Dynabeads Mouse T-Activator CD3/CD28 (Gibco). For the condition using T cells from TNF $\alpha$ KO mice, $3 \times 10^{5}$ TNF $\alpha$ $\mathrm{KO} \mathrm{CD} 3^{+} \mathrm{CD} 25^{-} \mathrm{T}$ cells were activated with Dynabeads Mouse T-Activator CD3/CD28 and co-cultured with $3 \times 10^{4}$ WT-MSCs (1/10 ratio MSCs/T cells). After 3 days, $\mathrm{T}$ cells were collected and immunostained using the following Abs: CD4-VIOBLUE, CD8 $\alpha$-FITC, CD25PE-Cy7, CTLA4-PE, TNFR2-APC (Miltenyi), and Foxp3-PE-Cy5 (eBioscience).

\section{Statistical analysis}

Prism (GraphPad) was used for statistical analysis. Shapiro-Wilk normality test was performed to assess the normal distribution of data. Then, Student $t$ test or 1way ANOVA with post hoc analysis was performed depending on the number of comparatives. For cytometry analysis, we have normalized the MFI values with $\mathrm{T}$ cell alone control group. Then, we used unpaired, 2-tailed Student $t$ tests or 1-way ANOVA for $P$ value generation.

\section{Results}

\section{MSC characterization}

First, we assessed if BM-MSCs harvested from WT and TNFR2 KO mice are pure cells with normal physiological functions. Both were able to adhere to plastic plates and proliferate until late passages. While WTMSCs showed normal morphological appearance, TNFR2 KO-MSCs were more heterogeneous with lower proliferation rate at passages 0 and 1 (Fig. 1a). The proliferation rate became equivalent to that of WT-MSCs in latter passages (data not shown). Moreover, both WT and TNFR2 KO-MSCs were positive for murine MSC markers such as CD44, CD105, CD73, CD90, and Sca-1 and negative for CD34 and CD45 markers (Fig. 1b). In addition, we demonstrated their capacity to differentiate into osteocytes and adipocytes under appropriate conditions (Fig. 1c, d).

\section{The MSC suppressive effect is decreased in the absence of the TNFa/TNFR2 signaling pathway}

MSCs inhibit T cell proliferation in response to mitogenic stimuli and $\mathrm{CD} 3 / \mathrm{CD} 28$ stimulation. Here, we investigated the role of the TNF $\alpha /$ TNFR2 axis in the ability of MSCs to suppress $\mathrm{T}$ cell proliferation. WT and TNFR2 KOMSCs were co-cultured with $\mathrm{CFSE}^{+} \mathrm{CD}^{+} \mathrm{CD} 25^{-} \mathrm{T}$ cells in 6 different ratios. $\mathrm{CD} 25^{+} \mathrm{T}$ cells were depleted from the primary population of $\mathrm{T}$ cells to eliminate activated $\mathrm{T}$ cells and non-specific immunosuppression by $\mathrm{T}$ regs. After 3 days, $\mathrm{T}$ cells were collected and the proliferation capacity of $\mathrm{CD}^{+}$and $\mathrm{CD} 8^{+}$populations was quantified. Since two different culture media were used for T cells and MSCs (RPMI and MEM $\alpha$, respectively), we used a 1:1 mix in coculture conditions. No difference was observed between $\mathrm{T}$ cells cultured in 100\% RPMI or in 50\% MEM $\alpha-50 \%$ RPMI (Fig. 2a, b). In all the ratios, $\mathrm{CD} 4^{+} \mathrm{CD} 25^{-}$(Fig. 2a) and $\mathrm{CD}^{+} \mathrm{CD}^{2} 5^{-}$(Fig. 2b) responder $\mathrm{T}$ cells in co-culture with WT or TNFR2 KO-MSCs proliferated less than anti-CD3/ CD28-activated T cells alone (T cells + B RPMI). Interestingly, we observed that WT-MSCs were significantly more immunosuppressive than TNFR2 KO-MSCs for both CD4 and CD8 $\mathrm{T}$ cell proliferation (Fig. $2 \mathrm{a}-\mathrm{C}$ ). A significant difference in immunosuppressive effect between WT and TNFR2 KO-MSCs was observed starting from $1 / 4$ ratio for $\mathrm{CD}^{+} \mathrm{T}$ cells $(22.91 \%$ and $49.60 \%$ of proliferation, respectively) and also for $\mathrm{CD}^{+} \mathrm{T}$ cells $(33.56 \%$ and $62.41 \%$ of proliferation, respectively). This difference was obvious until $1 / 10$ ratio for $\mathrm{CD}^{+} \mathrm{T}$ cells $(55.28 \%$ and $75.31 \%$ of proliferation, respectively) and for $\mathrm{CD}^{+} \mathrm{T}$ cells $(63.13 \%$ and $84.63 \%$ of proliferation, respectively). This is the first evidence of a significant dose-dependent immunosuppressive effect of MSCs on T cells that is more accentuated in WT-MSCs than in TNFR2 KO-MSCs. However, the absence of TNFR2 did not entirely abolish the MSC immunosuppressive potential.

\section{Expression of TNFR2 on MSCs is correlated to increased $\mathrm{CD}^{+}$conventional $\mathrm{T}$ cell immunomodulation}

We next investigated if the ability of MSCs to modulate the activation profile of $\mathrm{CD} 4^{+} \mathrm{T}$ cells is also TNFR2 dependent. WT and TNFR2 KO-MSCs were co-cultured for 3 days with anti-CD3/CD28-activated WT-CD $3^{+} \mathrm{CD} 25^{-} \mathrm{T}$ cells at a fixed $1 / 5$ ratio (MSCs/T cells). $\mathrm{T}$ cells were then collected and analyzed for the percentage of expression and the mean fluorescence intensity (MFI) of different activation markers for conventional $\mathrm{CD}^{+}{ }^{+} \mathrm{Foxp}^{-} \mathrm{T}$ cells $(\mathrm{CD} 4 \mathrm{~T}$ convs). We first measured the expression of CD25; the $\alpha$ chain of the IL-2 receptor constitutively expressed on the surface of $\mathrm{T}$ reg and activated $\mathrm{T}$ convs $[46,48]$. After 3 days, we observed a dramatic decrease in the percentage of $\mathrm{CD} 25^{+}$cells and $\mathrm{CD} 25$ expression level in $\mathrm{CD} 4^{+} \mathrm{T}$ convs when co-cultured with WT or TNFR2 KO-MSCs (Fig. 3). However, this decrease was significantly higher for WT than TNFR2 KO-MSCs. We also evaluated the expression of two members of the TNF $\alpha$ receptor superfamily, GITR (TNFRSF18) and TNFR2 (TNFRSF1B), both important in $\mathrm{T}$ cell biology and expressed by activated $\mathrm{T}$ cells $[49,50]$. Three days after, we observed a decrease in the percentage of $\mathrm{GITR}^{+}$cells and MFI of GITR on $\mathrm{CD}^{+} \mathrm{T}$ convs compared to $\mathrm{T}$ cells alone. No significant difference was observed between WT and TNFR2 KO-MSCs (Fig. 3). For 
A
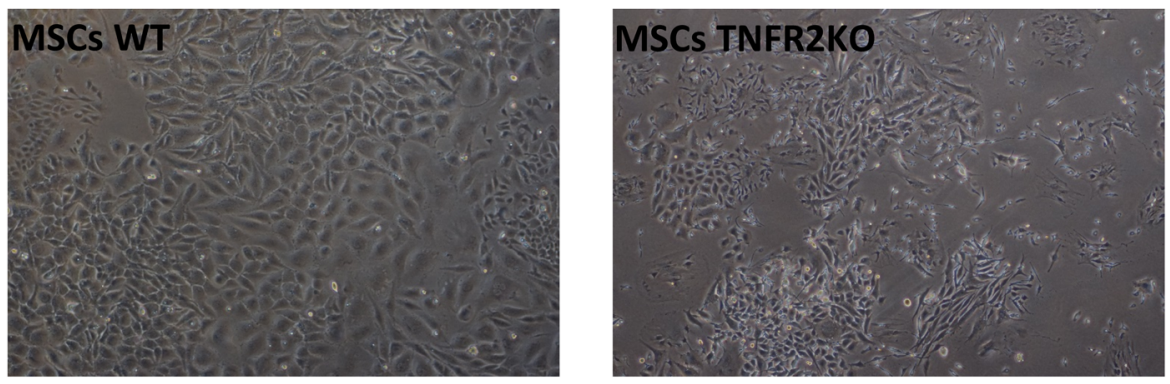

\section{B}
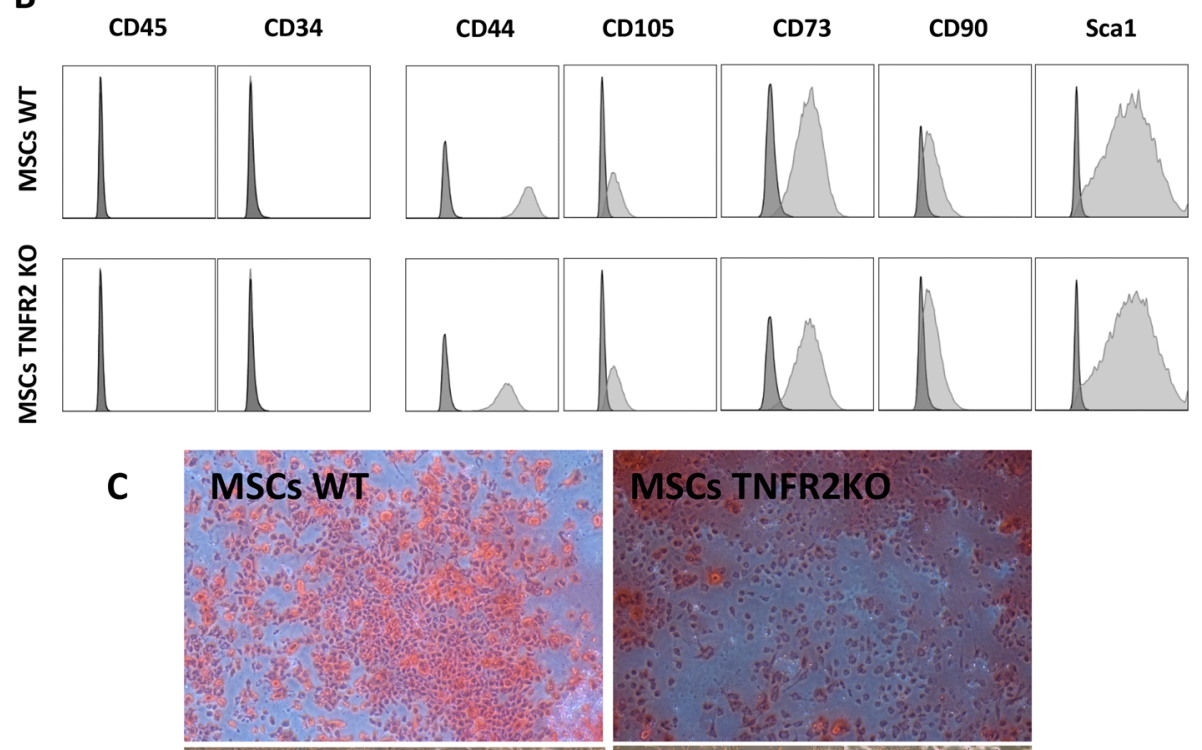

D
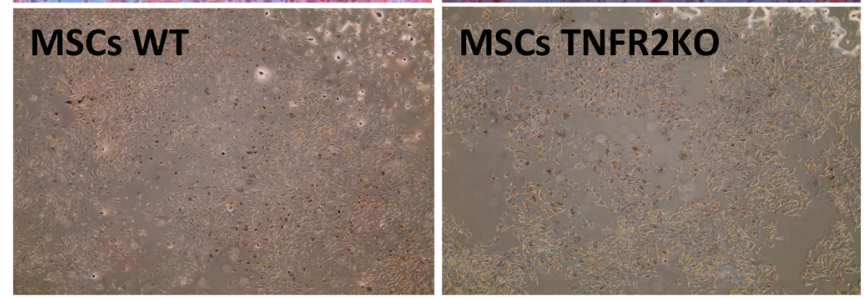

Fig. 1 MSC WT and TNFR2 KO characterization. a MSCs WT showed normal spindle-shaped fibroblast-like appearance $($ passage 3$)(\times 4)$ while MSCs TNFR2 KO exhibited a more heterogeneous morphology (passage 3) ( $\times 4$ ). b Flow cytometry analyses of the surface expression of CD45, CD34, CD44, CD105, CD73, CD90, and SCA1 in MSCs WT and TNFR2 KO (passage 3). Both MSC populations were negative for CD45 and CD34 and positive for the rest of the markers studied. The dark gray histograms represent isotype controls. Data are representative of $n=6$ in 3 independent experiments. c Osteogenic differentiation: both MSCs WT and TNFR KO (passage 3) were incubated in osteogenic differentiation medium for 17 days followed by Alizarin Red S staining ( $\times 4$ ). $\mathbf{d}$ Adipogenic differentiation: both MSCs WT and TNFR2 KO (passage 3) were incubated in adipogenic differentiation medium for 21 days followed by Oil Red $\mathrm{O}$ staining $(\times 4)$

TNFR2 expression, we noticed a significant decrease in the percentage of TNFR2 ${ }^{+}$cells among $\mathrm{CD} 4^{+} \mathrm{T}$ convs when cocultured with WT or TNFR2 KO-MSCs compared to T cells alone (Fig. 3). This decrease was more important for WT than for TNFR2 KO-MSCs. However, for MFI of TNFR2 on $\mathrm{CD}_{4}^{+} \mathrm{T}$ convs, we noticed a decrease when cocultured with WT but an increase with TNFR2 KO-MSCs. Finally, we studied the expression of ICOS among
$\mathrm{CD} 4^{+} \mathrm{T}$ convs. ICOS co-stimulatory receptor is essential for $\mathrm{T}$ cell activation and proliferation [51]. After 3 days of co-culture, we observed a significant reduction in the percentage of $\mathrm{ICOS}^{+}$cells and ICOS expression level among $\mathrm{CD}^{+} \mathrm{T}$ convs when co-cultured with WT or TNFR2 KO-MSCs (Fig. 3). This decrease was significantly more important for $\mathrm{T}$ cells cocultured with WT than with TNFR2 KO-MSCs. 
A

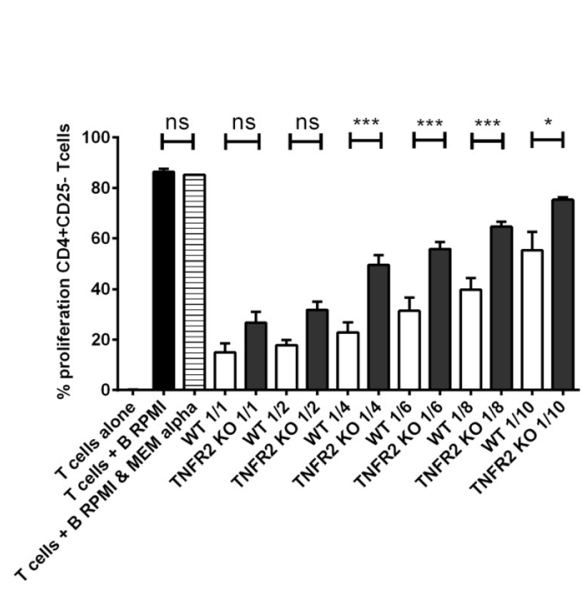

B

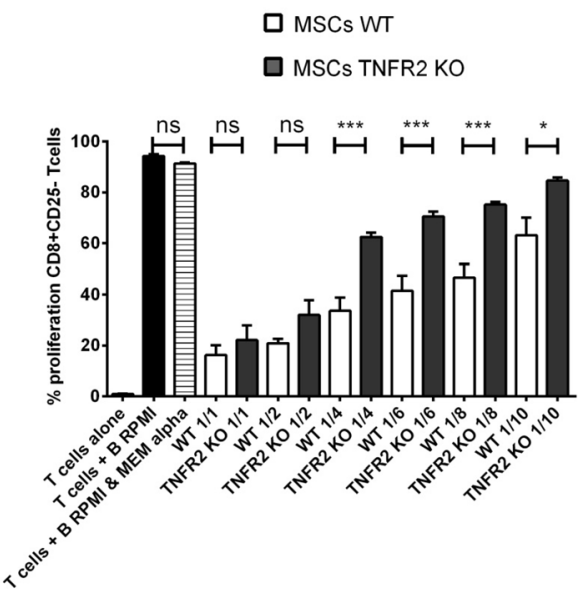

C

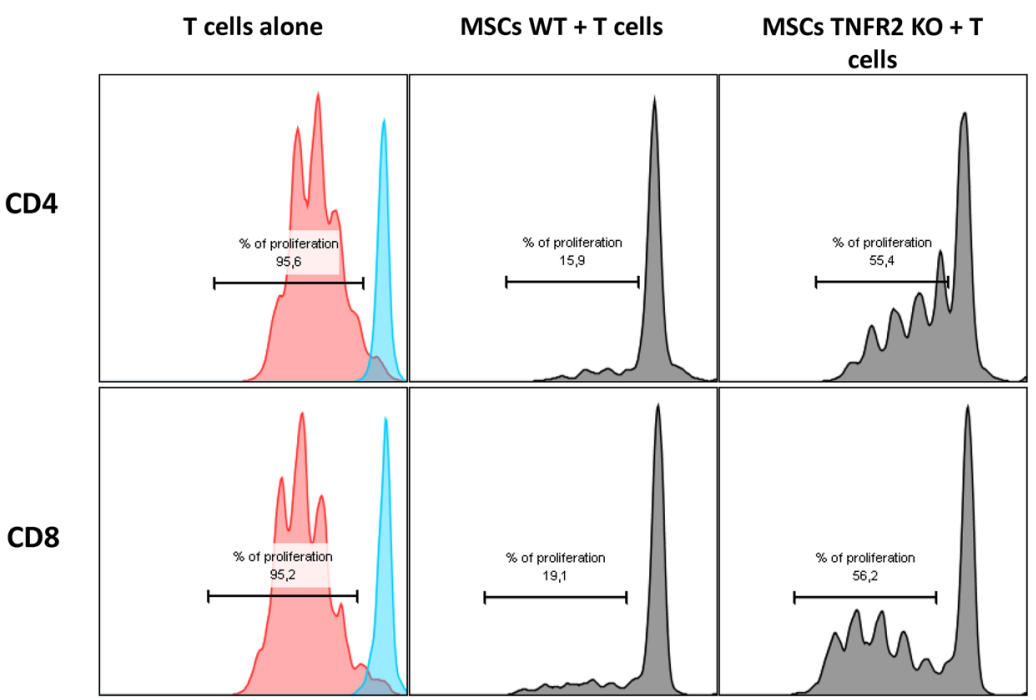

Fig. 2 MSCs' suppressive effect is diminished in the absence of the TNFa/TNFR2 signaling pathway. Activated CFSE $\mathrm{CD}^{+} \mathrm{Or} \mathrm{CD8}^{+}$ effector T cells were co-cultured with MSCS WT or TNFR2 KO in different MSC/T cell ratios $(n=6)$. Proliferation of CD4 ${ }^{+}$T cells (a) and $\mathrm{CD}^{+} \mathrm{T}$ cells $(\mathbf{b})$ was measured by flow cytometry. The first bar represents the unstimulated T cells alone $(n=6)$, the second bar represents the bead-stimulated T cells alone in RPMI $(n=8)$, and the third bar is for the stimulated T cells alone in $50 \%$ RPMI+50\% MEMa $(n=6)$. All data are collected from 3 different experiments. c A flow cytometry representative of proliferation assay at a 1:4 MSC/T cell ratio. Non-stimulated T cells have a single peak represented in blue. Upon stimulation, T cells alone or in co-culture with MSCs start to proliferate, and one can see less intensity of CFSE fluorescence. Data are represented as mean value \pm SEM. One-way ANOVA analysis was performed to generate $P$ values. ns, non-significant; ${ }^{*} P<.05,{ }^{* *} P<.01,{ }^{* * *} P<.001,{ }^{*}{ }^{* *} P<.0001$. b Anti-CD3 and anti-CD28 activation beads

\section{Expression of TNFR2 on MSCs is correlated to increased $\mathrm{CD}^{+}$conventional T cell immunomodulation}

To investigate the role of TNFR2 expression by MSCs on the cytotoxic $\mathrm{T}$ cell activation profile, WT and TNFR2 KO-MSCs were co-cultured for 3 days with anti$\mathrm{CD} 3 / \mathrm{CD} 28$ activated WT-CD ${ }^{+} \mathrm{CD} 25^{-} \mathrm{T}$ cells at a $1 / 5$ ratio (MSCs/T cells). T cells were then collected and analyzed for the percentage of expression and MFI of different activation markers of conventional $\mathrm{CD}^{+}{ }^{+} \mathrm{Foxp}^{-} \mathrm{T}$ cells (CD8 T convs). We observed a dramatic decrease in the percentage of $\mathrm{CD}^{+} 5^{+}$cells and CD25 expression level in $\mathrm{CD}^{+} \mathrm{T}$ convs when co-cultured with WT or TNFR2 KO-MSCs (Fig. 4). However, this effect was more accentuated in the presence of WT-MSCs versus TNFR2 KO-MSCs. Furthermore, analysis of GITR showed a decrease in the percentage of $\mathrm{GITR}^{+}$cells and MFI of GITR on $\mathrm{CD}^{+} \mathrm{T}$ convs. This decrease was significantly more important for WT than TNFR2 KO- 


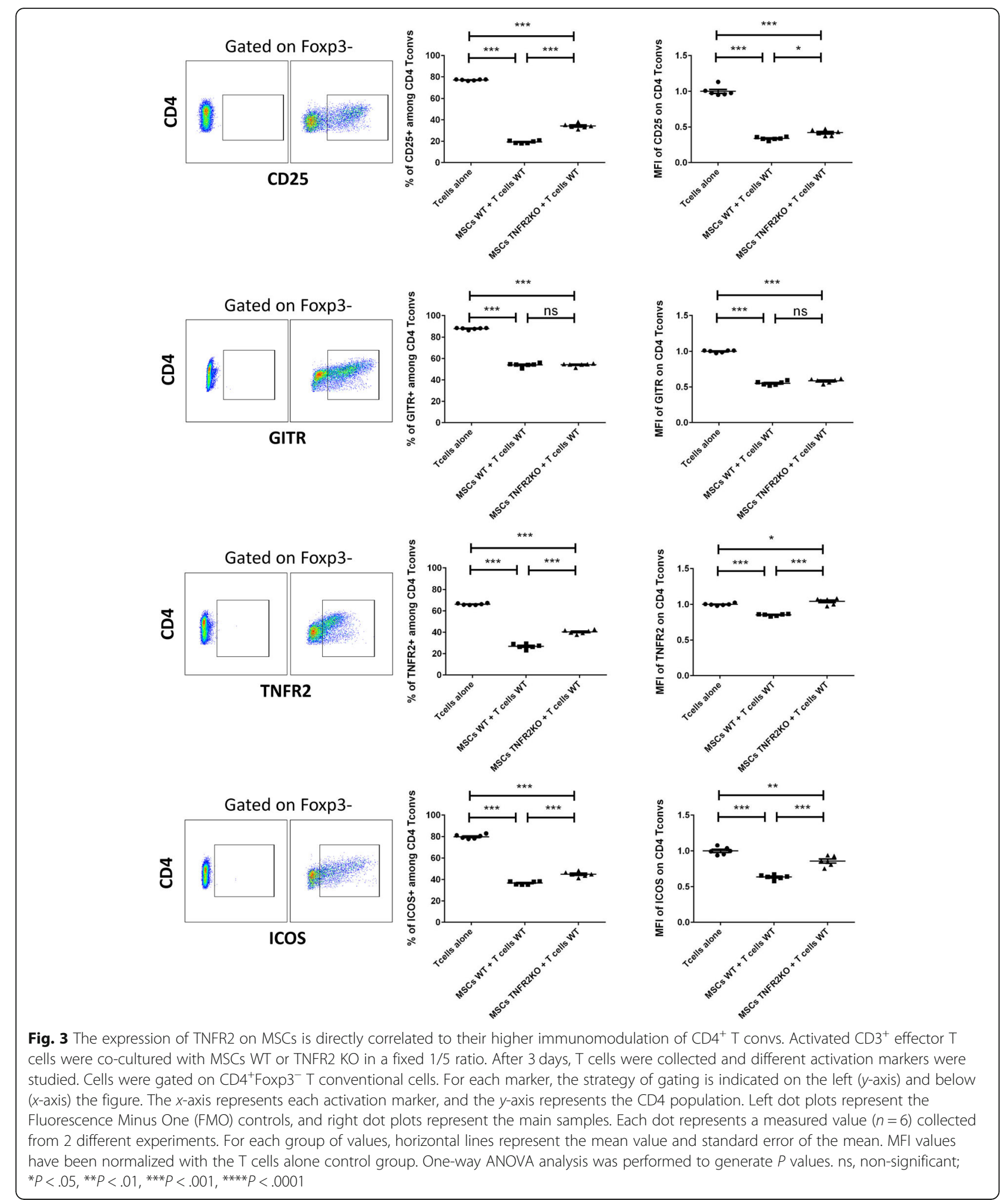

MSCs. For TNFR2, we observed a decrease in the percentage of TNFR2 ${ }^{+}$cells in $\mathrm{CD}^{+} \mathrm{T}$ convs co-cultured with WT or TNFR2 KO-MSCs (Fig. 4). Once again, this decrease was more significant for WT-MSCs versus
TNFR2 KO-MSCs. We found no decrease in MFI of TNFR2 but a significant increase when co-cultured with TNFR2 KO-MSCs. Finally, we studied the expression of ICOS on $\mathrm{CD} 8^{+} \mathrm{T}$ conv. There was a notable decrease in 


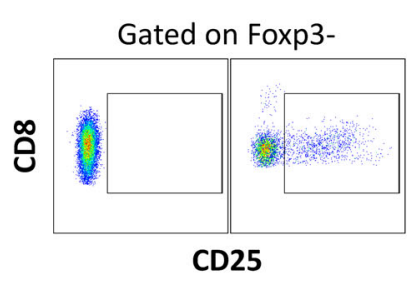

CD25

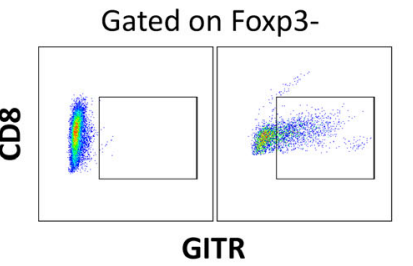

仓ั

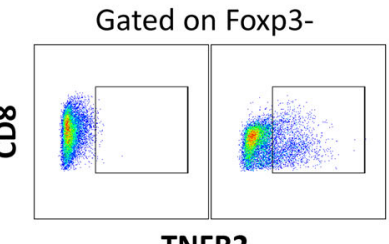

TNFR2

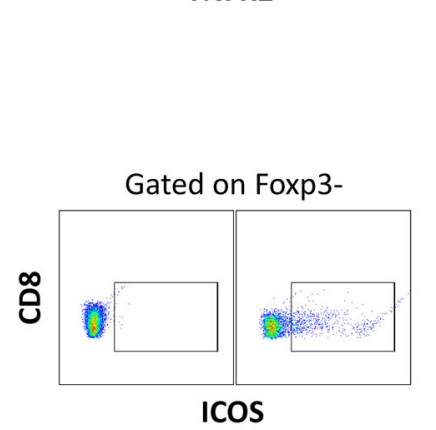

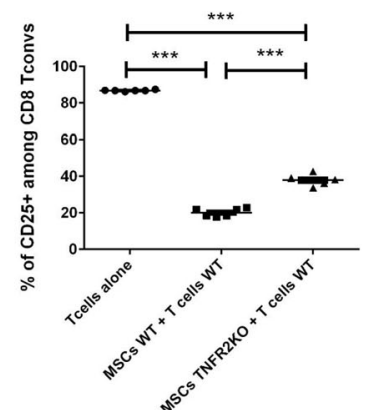
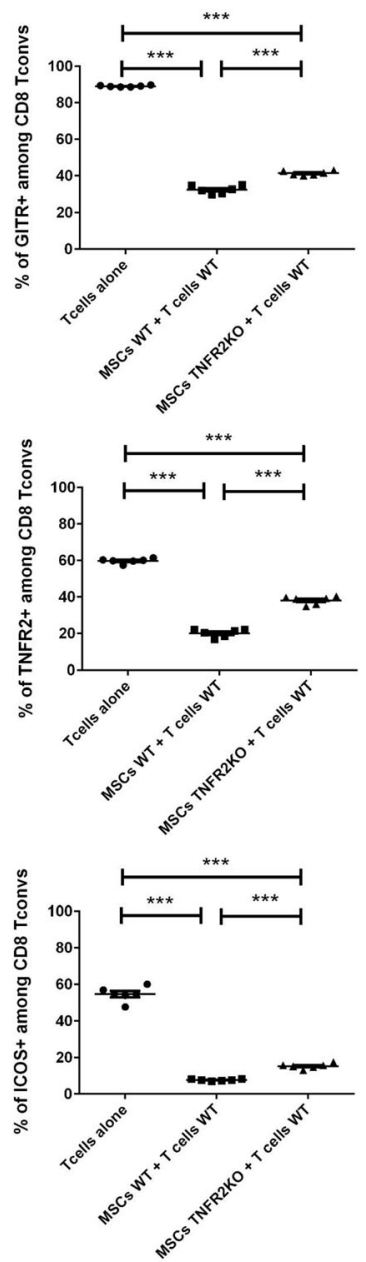
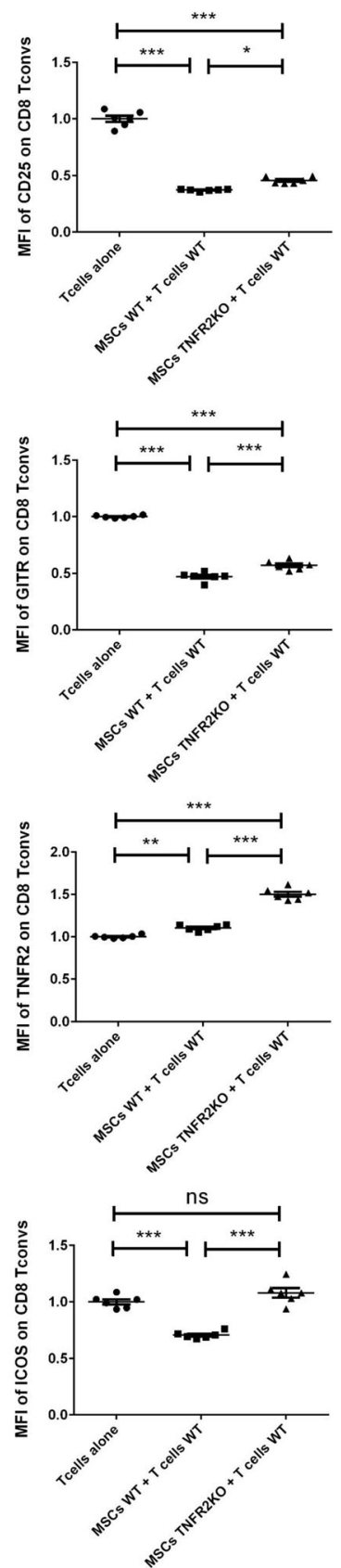

Fig. 4 The expression of TNFR2 on MSCs is directly correlated to their higher immunomodulation of $C D 8^{+} \mathrm{T}$ convs. Activated $C D 3^{+}$effector T cells were co-cultured with MSCs WT or TNFR2 KO in a fixed 1/5 ratio. After 3 days, T cells were collected and different activation markers were studied. Cells were gated on $\mathrm{CD}^{+}{ }^{+}$Foxp3 $3^{-}$T conventional cells. For each marker, the strategy of gating is indicated on the left ( $y$-axis) and below $(x$-axis) the figure. The $x$-axis represents each activation marker, and the $y$-axis represents the CD8 population. Left dot plots represent the Fluorescence Minus One (FMO) controls, and right dot plots represent the main samples. Each dot represents a measured value $(n=6)$ collected from 2 different experiments. For each group of values, horizontal lines represent the mean value and standard error of the mean. MFI values have been normalized with the T cells alone control group. One-way ANOVA analysis was performed to generate $P$ values. ns, non-significant; ${ }^{*} P<.05,{ }^{* *} P<.01,{ }^{* * *} P<.001,{ }^{* * *} P<.0001$

the percentage of $\mathrm{ICOS}^{+}$cells, when co-cultured with WT or TNFR2 KO-MSCs. This decrease was more important with WT-MSCs than TNFR2 KO-MSCs. A significant decrease in MFI of ICOS on $\mathrm{CD}^{+} \mathrm{T}$ convs was observed only when co-cultured with WT-MSCs (Fig. 4). 
MSCs modulate the capacity of T cells to produce proand anti-inflammatory cytokines via the TNFa/TNFR2 signaling pathway

After activation, $\mathrm{T}$ cells produce pro- or anti-inflammatory cytokines. We examined whether blocking the TNFa/ TNFR2 signaling pathway in MSCs modifies T cell cytokine production. We focused on principle cytokines secreted by the four main subpopulations of T helper cells (Th1, Th2, Th17, and $\mathrm{T}$ reg) and cytotoxic $\mathrm{T}$ cells (Tc1, Tc2, Tc17, and $\mathrm{T}$ reg). WT and TNFR2 KO-MSCs were co-cultured with WT-CD3 ${ }^{+} \mathrm{CD} 25^{-} \mathrm{T}$ cells. After 3 days, $\mathrm{T}$ cells were collected and analyzed for their cytokine production capacity. At first, we investigated the capacity of $\mathrm{T}$ cells to produce different pro-inflammatory cytokines. Interestingly, we observed a significant reduction in $\mathrm{CD} 4^{+} \mathrm{T}$ convs producing IFN $\gamma$, TNF $\alpha$, IL-2, and IL-17 when co-cultured with WT or TNFR2 KO-MSCs, compared to control T cells. This decrease was more significant for WT-MSCs compared to TNFR2 KO-MSCs (Fig. 5a). In CD8 ${ }^{+} \mathrm{T}$ convs, we did not observe a significant decrease in IFNy-producing $\mathrm{T}$ cells while co-cultured with WT-MSCs; however, there was a notable increase in IFN $\gamma$-producing $\mathrm{CD}^{+} \mathrm{T}$ cells while cocultured with TNFR2 KO-MSCs (Fig. 5b). Regarding TNF $\alpha$ and IL-17, a reduced production capacity was noticed merely by $\mathrm{CD}^{+} \mathrm{T}$ convs co-cultured with WT-MSCs and not TNFR2 $\mathrm{KO}$ (Fig. 5b). Co-culture of $\mathrm{CD}^{+} \mathrm{T}$ convs with WT or TNFR2 KO-MSCs led to a significant decrease in IL-2 production that was stronger with WT cells (Fig. 5b).

We then investigated whether co-culturing $\mathrm{T}$ convs with MSCs alters T cell anti-inflammatory cytokine production. We measured the production of IL-10 and TGF $\beta$ by T cells in the presence of MSCs. There was an increase in IL-10-producing cells in $\mathrm{CD} 4^{+} \mathrm{T}$ cells cocultured with WT or TNFR2 KO-MSCs, which was significantly higher with WT-MSCs (Fig. 5c). We found no increase in TGF $\beta$-producing $\mathrm{CD} 4^{+} \mathrm{T}$ cells co-cultured with either of MSCs (Fig. 5c). Additionally, we observed a significant increase in IL-10-producing $\mathrm{CD} 8^{+} \mathrm{T}$ cells merely while co-cultured with WT-MSCs. Finaly, we noticed an increased TGF $\beta$-producing $\mathrm{CD}^{+} \mathrm{T}$ cells cocultured with either of MSCs but remarkably higher for the WT-MSCs group (Fig. 5d).

\section{Expression of TNFR2 by MSCs is correlated to their higher Foxp ${ }^{+} \mathrm{T}$ reg induction capacity}

We and others have clearly shown that one of the main immunoregulatory mechanisms of MSCs is the induction of $\mathrm{T}$ regs (iTregs) from $\mathrm{T}$ convs. Here, we focused on the role of the TNF $\alpha / T N F R 2$ signaling pathway in this process. To investigate the ability of MSCs to convert $\mathrm{CD}^{+} \mathrm{CD} 25^{-} \mathrm{T}$ convs to Foxp $3^{+} \mathrm{T}$ regs, MSCs were cocultured with anti-CD3/CD28-activated $\mathrm{CD}^{+} \mathrm{CD} 25^{-} \mathrm{T}$ cells at 6 different ratios. $\mathrm{CD} 25^{+} \mathrm{T}$ cells were depleted to eliminate the unspecific expansion of natural $\mathrm{T}$ regs. After

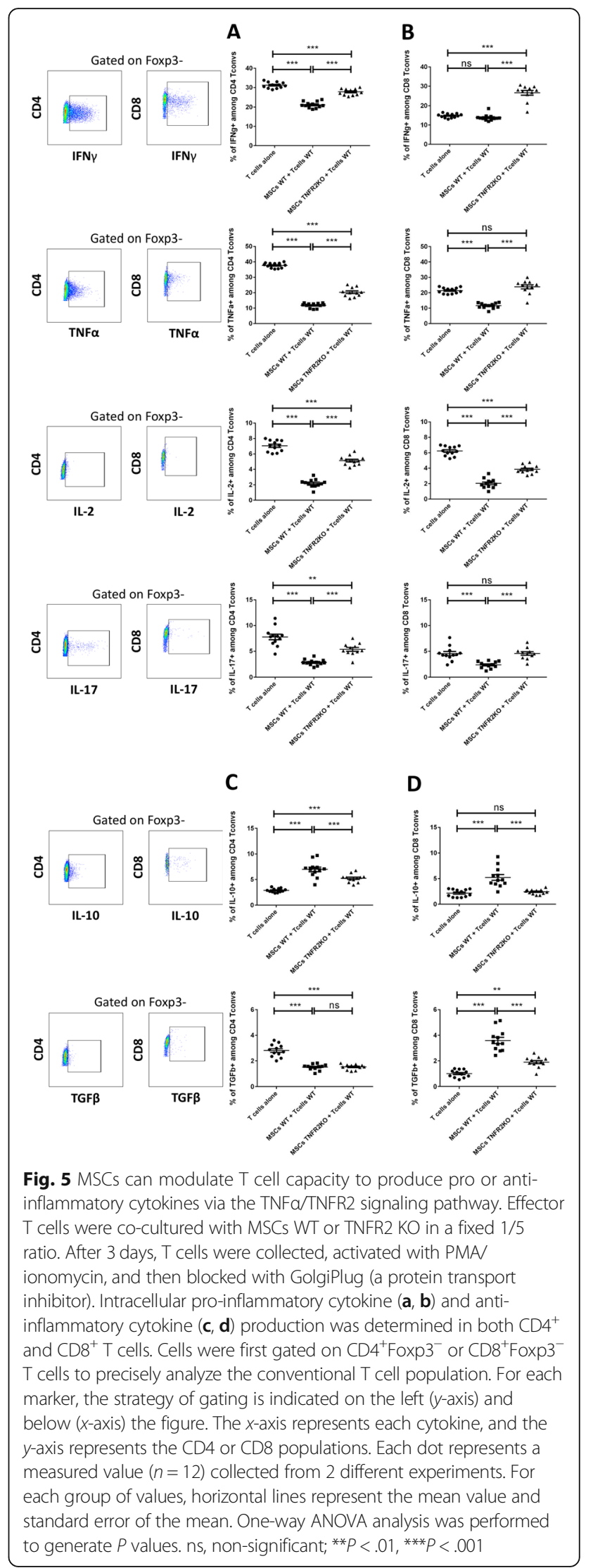


3 days of co-culture, $\mathrm{T}$ cells were collected and analyzed for Foxp3 expression. In all conditions, both $\mathrm{CD}_{4}^{+}$(Fig. 6a) and $\mathrm{CD}^{+} \mathrm{T}$ cells (Fig. $6 \mathrm{~b}$ ) in co-culture with WT or TNFR2 KO-MSCs expressed more Foxp3 than in the control $\mathrm{T}$ cells alone in a dose-dependent manner. In the $\mathrm{CD} 4^{+}$population, $1.89 \%$ of the $\mathrm{T}$ cells expressed Foxp3 at day 0 , i.e., immediately after the elimination of $\mathrm{CD} 25^{+}$ subpopulation ( $\mathrm{T}$ cells alone). This value significantly increased after co-culturing with WT or TNFR2 KO-MSCs, reaching to $13.43 \%$ and $8.45 \%$, respectively, in $1 / 1$ ratio and kept rising until $42.93 \%$ and $24.07 \%$, respectively, in $1 / 10$ ratio (Fig. 6a). In the $\mathrm{CD}^{+}$population, $1.22 \%$ of the $\mathrm{T}$ cells expressed Foxp3 at day 0 , after the elimination of $\mathrm{CD} 25^{+}$subpopulation. This value significantly increased after co-culturing with WT or TNFR2 KO-MSCs, reaching to $6.38 \%$ and $2.66 \%$, respectively, in $1 / 1$ ratio and kept rising until $19.30 \%$ and $9 \%$, respectively, in $1 / 10$ ratio (Fig. 6b).

To reinforce our results, we disrupted this signaling pathway via blocking the TNF $\alpha$ production by T cells. In this context, MSCs express TNFR2 but receive no signals from $\mathrm{T}$ cells. WT-MSCs were co-cultured with anti-CD3/CD28-activated $\mathrm{CD}^{+} \mathrm{CD} 25^{-} \mathrm{T}$ cells harvested from WT or TNF $\alpha$ KO mice in a fixed ratio $(1 / 10$ $\mathrm{MSCs} / \mathrm{T}$ cells, i.e., the most efficient ratio to induce Foxp3 expression) for 3 days. As expected, the percentage of Foxp $3^{+} \mathrm{T}$ regs among $\mathrm{CD} 4^{+} \mathrm{T}$ convs was significantly less in TNF $\alpha$ KO-T cells compared to WT T cells (35.86\% and 63.2\%, respectively) (Fig. 6c). Thus, two different approaches confirm the critical role of the TNF $\alpha$ / TNFR2 signaling pathway in T reg induction by MSCs.

\section{Expression of TNFR2 on MSCs leads to induction of T regs with a more active phenotype}

To characterize the activation profile of $\mathrm{CD}^{+}{ }^{+} \mathrm{Foxp}_{3}{ }^{+} \mathrm{i}$ Tregs, we quantified different activation markers, such as CD25, CTLA4, and TNFR2. The percentage of CD25 cells and the CD25 expression level on $\mathrm{CD} 4^{+} \mathrm{Foxp} 3^{+}{ }^{+}$Tregs was significantly higher after co-culture with WT-MSCs than with TNFR2 KO-MSCs (Fig. 7). The same results were observed for the CTLA4 expression (Fig. 7). We and others have shown that one of the most important regulators of T reg activity is TNFR2 which is directly related to their activation and immunosuppressive function [38, 52]. We found that the percentage of TNFR2 ${ }^{+} \mathrm{iTregs}$ from coculture with WT-MSCs was significantly higher than TNFR2 KO-MSCs (Fig. 7). No significant difference was observed for MFI of TNFR2 in different conditions. Thus, TNFR2 ${ }^{+}$MSCs were able to induce more active Foxp $3^{+} \mathrm{T}$ regs compared to TNFR2 ${ }^{-}$MSCs.

\section{Discussion}

Since MSCs display wound healing [53], immunomodulatory, and anti-inflammatory effects [25-27], they are ideal choices for cell therapy applications. First clinical trials were performed with autologous MSCs, but those treatments were patient-specific, inefficient, and expensive [54]. Then, converging evidences showed that allogenic MSCs have comparable efficacy, without immune rejection issues [55]. This established interesting perspectives for broader administration of MSCs in clinics using banks of allogenic MSCs from different tissue origins. Therefore, it is crucial to understand the mechanisms behind MSC immunoregulatory activity.

Here, we performed co-cultures of MSCs (WT and TNFR2 KO) and T cells (WT and TNF $\alpha \mathrm{KO}$ ) to investigate the effects of the TNF $\alpha / T N F R 2$ axis on MSC-T cell interaction. We have previously assessed and reported the viability of MSCs and T cells upon co-culturing in different conditions. The viability of cells was between 77 and $98 \%$ depending on the coculture condition [25-27].

Co-culture of activated CD4 ${ }^{+} \mathrm{Foxp}^{-}$and $\mathrm{CD} 8^{+} \mathrm{Foxp}^{-} \mathrm{T}$ cells with MSCs remarkably reduced their proliferation in a dose-dependent manner. Interestingly, this immunosuppressive effect was significantly decreased when TNFR2 KO-MSCs were used. Our data point that the TNF $\alpha /$ TNFR2 axis is an important but not the only regulator of MSC immunosuppressive function since TNFR2 KOMSCs were also immunosuppressive but less efficiently. We then measured the ability of MSCs to modify T conv activation profile by quantifying the expression of CD25, GITR, ICOS, and TNFR2 markers. While both MSCs were able to down-modulate $\mathrm{CD}^{+} \mathrm{Foxp}^{-}$and $\mathrm{CD}^{+} \mathrm{Foxp}^{-}{ }^{-} \mathrm{T}$ cell activation, this immunomodulatory effect was stronger with WT than TNFR2 KO-MSCs. Thus, we report a direct correlation between the TNFR2 expression and the MSC immunomodulatory effect. Among different $\mathrm{T}$ cell activation markers, we targeted two TNFa receptor superfamily members, GITR and TNFR2, and demonstrated a more significant decrease in their expression while $\mathrm{T}$ cells were co-cultured with WT-MSCs. This reflects a complex modulation of TNFa signaling in $\mathrm{T}$ cells in the presence of TNFR2 ${ }^{+}$MSCs. Accordingly, other studies showed when TNFR2 is decreased on T cells, they will be more efficiently suppressed by $\mathrm{T}$ regs [50] and here by MSCs. Furthermore, this downregulation was accompanied by a modification in $\mathrm{T}$ cell cytokine production. WT-MSCs decreased T cell pro-inflammatory cytokines like IFN $\gamma$, TNF $\alpha$, IL-2, and IL-17 and increased the antiinflammatory cytokines like IL-10 and TGF $\beta$. This effect was less or even totally hindered with TNFR2 KO-MSCs, pointing out the critical role of TNFR2 expression by MSCs. This is in agreement with studies reporting, upon TNF $\alpha$ activation, MSCs produce a higher level of immunosuppressive molecules such PGE2, TSG6, IL-8, CXCL5, CXCL6, and other growth factors like HGF, IGF1, and VEGF $[9,56,57]$. 
A
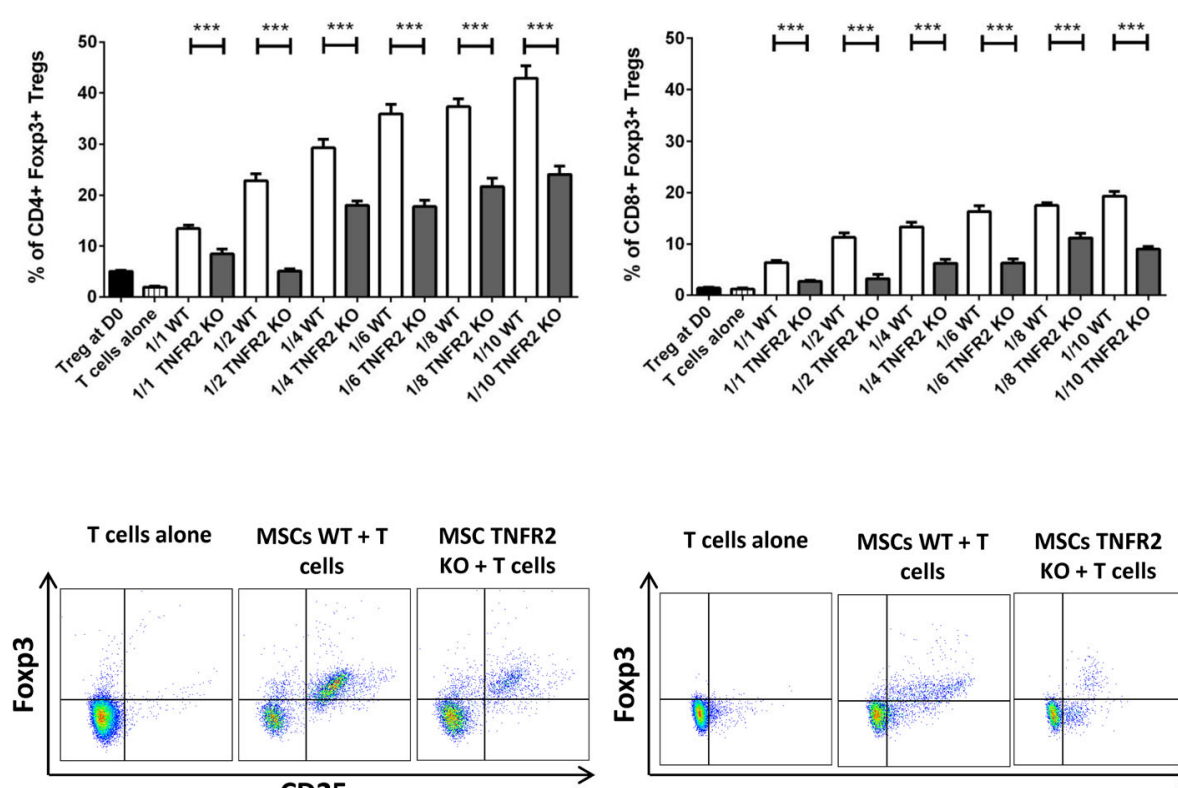

CD25

C

- Treg at D0

- MSCs WT + T cells WT

a MSCs WT + T cells TNFa KO
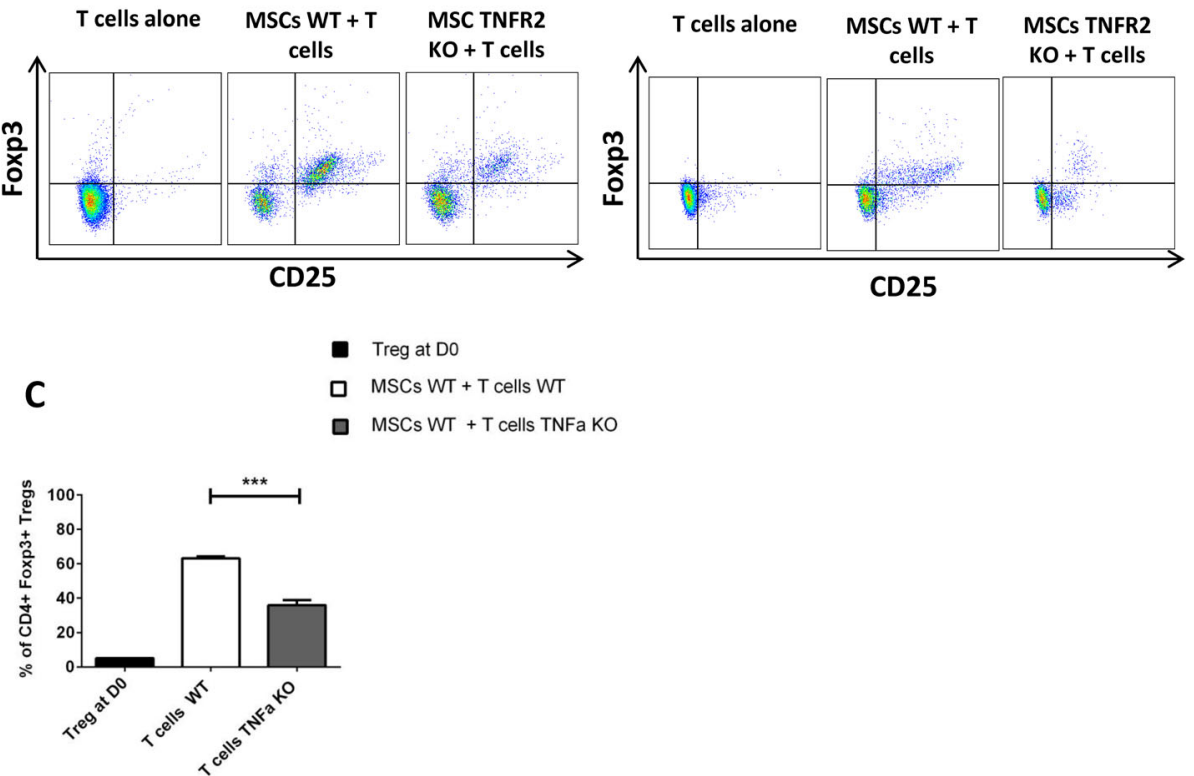

- Treg at Do

口 $T$ cells alone

口 MSCs WT + T cells

B $\square$ MSCs TNFR2 KO + T cells

Fig. 6 Expression of TNFR2 by MSCs is directly correlated to their higher Foxp3 T reg induction capacity. Activated $\mathrm{CD}^{+}{ }^{+}$or $\mathrm{CD} 8^{+}$effector T cells were co-cultured with MSCs WT or TNFR2 KO in different ratios $(n=9)$. After 3 days, the expression of Foxp3 among CD4 ${ }^{+} \mathrm{T}$ cells $(\mathbf{a})$ and CD $8^{+} \mathrm{T}$ cells (b) was measured by flow cytometry. Cells were gated on $\mathrm{CD} 4^{+} \mathrm{CD} 25^{+} \mathrm{Foxp} 3^{+}$or $\mathrm{CD} 8^{+} \mathrm{CD} 25^{+} \mathrm{Foxp} 3^{+} \mathrm{T}$ cells. The gating strategy is indicated on the left and under the figures. The first black bar represents the percentage of Foxp3-expressing cells among total effector T cells used in cocultures at day $0(n=9)$ while the second bar represents the percentage of Foxp3-expressing T cells alone after 3 days of culture $(n=9)$. (c) CD4 ${ }^{+}$ T cells collected from the spleen of WT or TNFa deficient mice were co-cultured with MSCs WT. Cells were gated on $\mathrm{CD}^{+} \mathrm{CD} 25^{+}$Foxp3 $3^{+}$. Data are represented as the mean value \pm SEM collected from 3 different experiments. One-way ANOVA or unpaired Student $t$ test analysis was performed to generate $P$ values; ${ }^{* * *} P<.001$. D0, day 0

Thereafter, we quantified the involvement of the TNF $\alpha /$ TNFR2 signaling pathway in the ability of MSCs to convert $\mathrm{T}$ convs to $\mathrm{CD} 4^{+} \mathrm{Foxp}^{+}$and $\mathrm{CD} 8^{+} \mathrm{Foxp} 3^{+} \mathrm{T}$ regs. Expectedly, this effect was more preeminent with TNFR2 ${ }^{+}$MSCs than with TNFR2 KO-MSCs. These results are encouraging, since $\mathrm{CD} 8^{+} \mathrm{T}$ regs are naturally rare population compared to their $\mathrm{CD}^{+}$counterparts. However, after co-culturing with TNFR2 ${ }^{+}$MSCs, $20 \%$ of
$\mathrm{CD} 8^{+} \mathrm{T}$ cells expressed Foxp3 which is double compared to TNFR2 KO-MSCs. To reinforce our results, we hampered the TNF $\alpha /$ TNFR2 axis by co-culturing WT-MSCs and TNF $\alpha \mathrm{KO}-\mathrm{T}$ convs that are incapable of TNF $\alpha$ production. Again, in the absence of TNF $\alpha$, the ability of T convs to differentiate into $\mathrm{T}$ regs was significantly decreased. Accordingly, it was demonstrated that pretreatment of MSCs with TNF $\alpha$ is crucial for the 

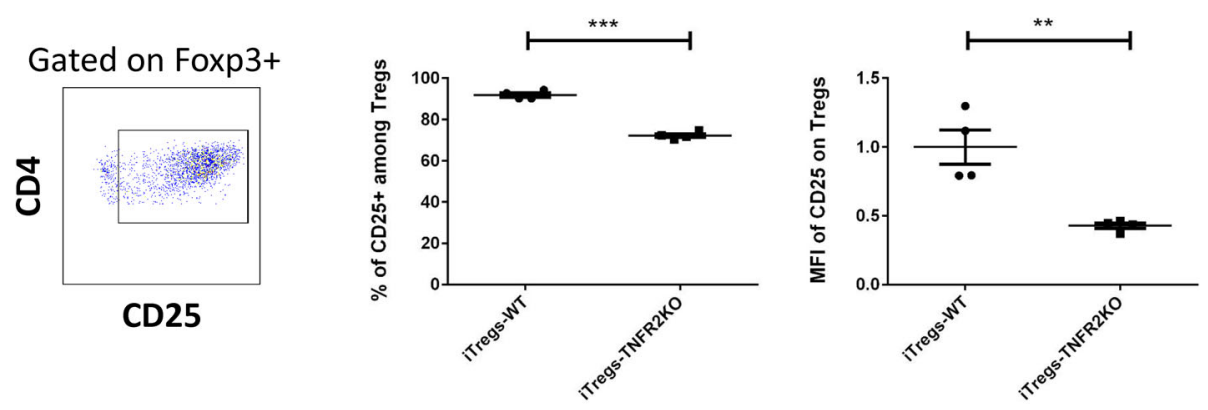

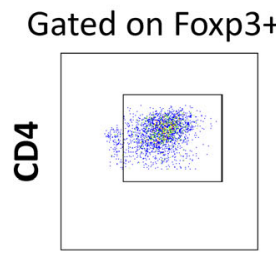

CTLA4

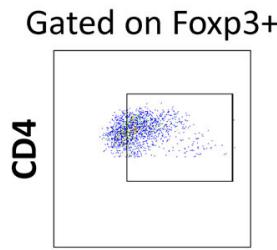

TNFR2
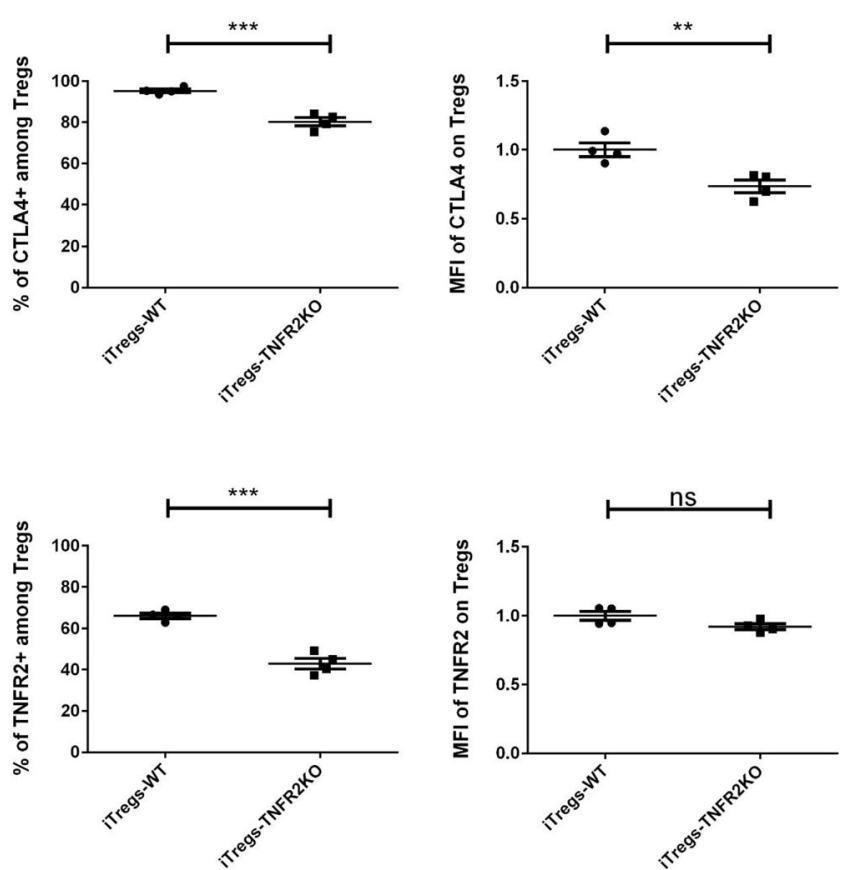

Fig. 7 The expression of TNFR2 on MSCs is leading to the induction of T regs with a more activated phenotype. The activation status of the T regs that were induced after the co-culture of $\mathrm{CD4}^{+}$conventional T cells with MSCs WT or TNFR2 KO was evaluated. Cells were gated on $\mathrm{CD}^{+}{ }^{+}$Foxp $3^{+} \mathrm{T}$ cells. For each marker, the strategy of gating is indicated on the left and under the figure. Each dot represents a measured value $(n=4)$ collected from 2 different experiments. For each group of values, horizontal lines represent the mean value and standard error of the mean. Unpaired Student $t$ test analysis was performed to generate $P$ values. ns, non-significant; ${ }^{* *} P<.01,{ }^{* * *} P<.001$. iTregs, induced T reg cells

polarization of macrophages towards more antiinflammatory M2 and less pro-inflammatory M1 subpopulation [57] and increased $\mathrm{T}$ reg repertory [58].

As demonstrated in the results, even TNFR2 KOMSCs show some level of immunoregulatory features; however, these effects are significantly less than WTMSCs. We believe that the presence of TNFR2 guarantees higher survival and less apoptosis rate. The expression of TNFR2 has been already correlated to increased IL-10 and TGF $\beta$ production $[40,59]$. As we have also shown, WT-MSCs are able to produce more of those anti-inflammatory cytokines, exerting more immunosuppressive effect. The absences of TNFR2 can negatively affect signaling through TNFR1 not only by decreasing functional cells but also by increasing the proinflammatory profile of surviving cells. It has been demonstrated that TNFR1 signaling promotes inflammation due to increased production of pro-inflammatory factors including TNF, IL-1 $\beta$, and IL-6 [60]. However, observing a certain level of immunoregulation by TNFR2 KO-MSCs reveals some form of crosstalk between the two receptors. Due to the absence of the death domain (DD) in the TNFR2 signaling pathway; TNFR1 and TNFR2 have two distinct functionalities. Nevertheless, both receptors (predominantly TNFR2) can activate the $\mathrm{NF}-\mathrm{kB}$ signaling pathway via the involvement of TNF receptor-associated factors (TRAFs) [61]. It has been demonstrated that TNFR family co-stimulation increases regulatory $\mathrm{T}$ cell activation and function via NF- $\mathrm{B}$ [62]. Moreover, it was shown that the NF-kB RelA subunit (p65) transcription factor is critical for $\mathrm{T}$ reg activation and stability [63]. This could explain why TNFR2 KO- 
MSCs maintain a certain level of immunoregulation and are still able to induce $\mathrm{T}$ regs.

TNFR2 is expressed by most of the known immunosuppressive cells. Our results are the first evidence proving TNFR2 as an active immune checkpoint for MSCs, enabling regulation of their immunological features. It was shown that TNFR $2^{+} \mathrm{T}$ regs are the most homogeneous population with the highest immunosuppressive function [64, 65]. MSCs are very heterogeneous stem cells, and this effects their functionality. It will be interesting to sort TNFR2 ${ }^{\text {hi }}$ MSCs to have the purest and the most immunosuppressive population.

In case of cancer, MSCs help tumor cells to evade immune attack, while promoting tumor angiogenesis [66]. They participate in many crucial steps from invasion and metastasis, including stimulating the epithelialmesenchymal transition and induction of stem-like properties that allow cancer stem cells to increase their survivability $[67,68]$. Using anti-TNFR2 treatment could be an efficient way to simultaneously hamper immunosuppression by $\mathrm{T}$ regs $[38,69]$ and other immunosuppressive cells present in the tumor microenvironment [70], to directly eliminate TNFR2 expressing tumor cell $[71,72]$, to interrupt angiogenesis [73], and to decrease MSC survival and function.

\section{Conclusions}

Our results reveal another mechanism that MSCs use to regulate immune response. Using different in vitro experimental approaches, we have demonstrated for the first time that the TNF $\alpha / T N F R 2$ signaling pathway is in control of the immunomodulatory properties of MSCs. Signaling through this immune checkpoint axis can modulate MSC ability to suppress $\mathrm{T}$ cell proliferation, activation, cytokine production, and their capacity to induce active $\mathrm{T}$ regs.

This work brings us one step closer to this conclusion that targeting TNFR2 using its proper antagonist is an effective way to direct immunoregulatory responses. Not only will it efficiently control immunosuppression by MSCs and other TNFR2 ${ }^{+}$immunosuppressive cells but also angiogenesis and cell survival, highlighting its important therapeutic potential in cases like cancer treatment. Inversely, boosting through TNFR2 via administration of its agonist could potentially elevate MSC immunoregulatory function favoring the cases such as transplantations in which increased anti-inflammatory responses are especially required.

\section{Abbreviations}

$B$ reg: Regulatory B cell; BM-MSCs: Bone marrow-derived mesenchymal stem cells; CD: Cluster of differentiation; CFSE: Carboxyfluorescein succinimidyl ester; DD: Death domain; EPCs: Endothelial progenitor cells; HGF: Hepatocyte growth factor; ICOS: Inducible co-stimulatory molecule; IFNY: Interferon gamma; IGF-1: Insulin-like growth factor 1; IL: Interleukin; iTreg: Induced regulatory T cell; mAB: Monoclonal antibody; MACS: Magnetic-activated cell sorting; MDCSs: Myeloid-derived suppressive cells; MFI: Mean fluorescence intensity; MSCs: Mesenchymal stem cells; P: Passage; Sca1: Stem cell antigen1; sTNFR2: Soluble tumor necrosis factor receptor 2; T conv: Conventional T cell; T eff: Effector T cell; T reg: Regulatory T cell; Tc: Cytotoxic T cells; Th: T helper cells; TNFR1: Tumor necrosis factor receptor 1; TNFR2 KO: Tumor necrosis factor receptor 2 knocked out; TNFR2: Tumor necrosis factor receptor 2; TNFa: Tumor necrosis factor alpha; TRAF: TNF receptor-associated factor; VEGF: Vascular endothelial growth factor

\section{Acknowledgements \\ Not applicable}

Authors' contributions

$\mathrm{SN}, \mathrm{HH}, \mathrm{BS}$, and GU conceived the study. GB and SN wrote and revised the manuscript. HH, and GU revised and corrected the manuscript. GB, MK, MEA, and SN performed the experiments. GB and SN analyzed the data. The authors read and approved the final manuscript.

\section{Funding}

This work was supported by a governmental grant via "I'Agence Nationale de la Recherche" in the form of "programme d'Investissements d'avenir" with the grand number: ANR_15-RHUS60002.

Miss. Ghada BELDI was supported by a scholarship from entitled "Bourse d'Alternance" attributed by Carthage University, Ministry of higher Education and scientific Research, Tunis, Tunisia.

\section{Availability of data and materials}

The datasets used and/or analyzed during the current study are available from the corresponding authors on reasonable request.

\section{Ethics approval and consent to participate}

All experimental procedures were performed in accordance with the European Community Council Directive (2010/63/UE) for the care and use of laboratory animals. Experimental protocols were approved by the local ethics committee "Comité d'éthique en expérimentation animal Charles Darwin No. 5" under the number 02811.03 in compliance with the European Union guidelines.

\section{Consent for publication}

Not applicable

\section{Competing interests}

Sina Naserian, Ph.D., is the CEO of CellMedEx Company.

The authors declare that they have no competing interests.

\section{Author details}

${ }^{1}$ INSERM UMR-S-MD 1197, Hôpital Paul Brousse, Villejuif, France. ${ }^{2}$ Paris-Saclay University, Villejuif, France. ${ }^{3}$ National Institute of Applied Sciences and Technology (INSAT), Carthage University, LR18ES40, Inflammation, environment and signalization pathologies, Tunis, Tunisia. ${ }^{4}$ Sorbonne Université, INSERM, CNRS, Centre d'Immunologie et des Maladies Infectieuses (CIMl-Paris), Paris, France. ${ }^{5}$ Biochemistry Division, Chemistry department, Faculty of Science, Helwan University, Cairo, Egypt. ${ }^{6}$ CellMedEx, Saint Maur Des Fossés, France.

Received: 28 January 2020 Revised: 30 April 2020 Accepted: 25 May 2020 Published online: 16 July 2020

\section{References}

1. Ullah I, Subbarao RB, Rho GJ. Human mesenchymal stem cells - current trends and future prospective. Biosci Rep 2015;35(2). doi:https://doi.org/10. 1042/BSR20150025.

2. Zhao S, Wehner R, Bornhäuser M, Wassmuth R, Bachmann M, Schmitz M. Immunomodulatory properties of mesenchymal stromal cells and their therapeutic consequences for immune-mediated disorders. Stem Cells Dev. 2010;19(5):607-14. https://doi.org/10.1089/scd.2009.0345.

3. Ghannam S, Bouffi C, Djouad F, Jorgensen C, Noël D. Immunosuppression by mesenchymal stem cells: mechanisms and clinical applications. Stem Cell Res Ther. 2010;1(1):2. https://doi.org/10.1186/scrt2. 
4. Gao F, Chiu SM, Motan DAL, et al. Mesenchymal stem cells and immunomodulation: current status and future prospects. Cell Death Dis. 2016;7:e2062. https://doi.org/10.1038/cddis.2015.327.

5. Le Blanc K, Ringdén O. Immunomodulation by mesenchymal stem cells and clinical experience. J Intern Med. 2007;262(5):509-25. https://doi.org/10. 1111/j.1365-2796.2007.01844.x.

6. Shi Y, Wang Y, Li Q, et al. Immunoregulatory mechanisms of mesenchymal stem and stromal cells in inflammatory diseases. Nat Rev Nephrol. 2018; 14(8):493-507. https://doi.org/10.1038/s41581-018-0023-5.

7. Bernardo ME, Zaffaroni N, Novara F, et al. Human bone marrow derived mesenchymal stem cells do not undergo transformation after long-term in vitro culture and do not exhibit telomere maintenance mechanisms. Cancer Res. 2007;67(19):9142-9. https://doi.org/10.1158/0008-5472.CAN-06-4690.

8. Ma S, Xie N, Li W, Yuan B, Shi Y, Wang Y. Immunobiology of mesenchymal stem cells. Cell Death Differ. 2014;21 (2):216-25. https://doi.org/10.1038/cdd. 2013.158.

9. Yan $L$, Zheng $D$, Xu R-H. Critical role of tumor necrosis factor signaling in mesenchymal stem cell-based therapy for autoimmune and inflammatory diseases. Front Immunol. 2018;9:1658. https://doi.org/10.3389/fimmu.2018. 01658.

10. Schurgers E, Kelchtermans H, Mitera T, Geboes L, Matthys P. Discrepancy between the in vitro and in vivo effects of murine mesenchymal stem cells on T-cell proliferation and collagen-induced arthritis. Arthritis Res Ther. 2010; 12(1):R31. https://doi.org/10.1186/ar2939.

11. Aggarwal S, Pittenger MF. Human mesenchymal stem cells modulate allogeneic immune cell responses. Blood. 2005;105(4):1815-22. https://doi. org/10.1182/blood-2004-04-1559.

12. Khosravi M, Azarpira N, Shamdani S, Hojjat-Assari S, Naserian S, Karimi MH Differentiation of umbilical cord derived mesenchymal stem cells to hepatocyte cells by transfection of miR-106a, miR-574-3p, and miR-451. Gene. 2018;667:1-9. https://doi.org/10.1016/j.gene.2018.05.028.

13. Afshari A, Shamdani S, Uzan G, Naserian S, Azarpira N. Different approaches for transformation of mesenchymal stem cells into hepatocyte-like cells. Stem Cell Res Ther. 2020;11(1):54. https://doi.org/10.1186/s13287-020-1555-8.

14. Liu Y, Wang S, Shi S. The role of recipient T cells in mesenchymal stem cellbased tissue regeneration. Int J Biochem Cell Biol. 2012;44(11):2044-50. https://doi.org/10.1016/j.biocel.2012.08.003.

15. English $\mathrm{K}$, Barry FP, Field-Corbett CP, Mahon BP. IFN-gamma and TNF-alpha differentially regulate immunomodulation by murine mesenchymal stem cells. Immunol Lett. 2007;110(2):91-100. https://doi.org/10.1016/j.imlet.2007.04.001.

16. Ghaneialvar H, Soltani L, Rahmani HR, Lotfi AS, Soleimani M. Characterization and classification of mesenchymal stem cells in several species using surface markers for cell therapy purposes. Indian J Clin Biochem IJCB. 2018; 33(1):46-52. https://doi.org/10.1007/s12291-017-0641-x.

17. Dominici M, Le Blanc K, Mueller I, et al. Minimal criteria for defining multipotent mesenchymal stromal cells. The International Society for Cellular Therapy position statement. Cytotherapy. 2006;8(4):315-7. https://doi.org/10.1080/14653240600855905.

18. Kaundal U, Bagai U, Rakha A. Immunomodulatory plasticity of mesenchymal stem cells: a potential key to successful solid organ transplantation. J Transl Med. 2018;16(1):31. https://doi.org/10.1186/s12967-018-1403-0.

19. Shi Y, Hu G, Su J, et al. Mesenchymal stem cells: a new strategy for immunosuppression and tissue repair. Cell Res. 2010;20(5):510-8. https://doi.org/ 10.1038/cr.2010.44.

20. Djouad F, Bouffi C, Ghannam S, Noël D, Jorgensen C. Mesenchymal stem cells: innovative therapeutic tools for rheumatic diseases. Nat Rev Rheumatol. 2009;5(7):392-9. https://doi.org/10.1038/nrrheum.2009.104.

21. Eggenhofer E, Luk F, Dahlke MH, Hoogduijn MJ. The life and fate of mesenchymal stem cells. Front Immunol. 2014;5:148. https://doi.org/10. 3389/fimmu.2014.00148.

22. Foronjy RF, Majka SM. The potential for resident lung mesenchymal stem cells to promote functional tissue regeneration: understanding microenvironmental cues. Cells. 2012;1(4):874. https://doi.org/10.3390/cells1040874.

23. Le Blanc K, Tammik L, Sundberg B, Haynesworth SE, Ringdén O. Mesenchymal stem cells inhibit and stimulate mixed lymphocyte cultures and mitogenic responses independently of the major histocompatibility complex. Scand J Immunol. 2003;57(1):11-20. https://doi.org/10.1046/j.13653083.2003.01176x

24. Djouad F, Plence P, Bony $C$, et al. Immunosuppressive effect of mesenchymal stem cells favors tumor growth in allogeneic animals. Blood. 2003;102(10):3837-44. https://doi.org/10.1182/blood-2003-04-1193.
25. Khosravi M, Bidmeshkipour A, Cohen JL, et al. Induction of CD4+CD25+ FOXP3+ regulatory T cells by mesenchymal stem cells is associated with modulation of ubiquitination factors and TSDR demethylation. Stem Cell Res Ther. 2018;9(1):273. https://doi.org/10.1186/s13287-0180991-1.

26. Khosravi M, Bidmeshkipour A, Moravej A, Hojjat-Assari S, Naserian S, Karimi $\mathrm{MH}$. Induction of CD4+CD25+Foxp3+ regulatory T cells by mesenchymal stem cells is associated with RUNX complex factors. Immunol Res. 2018; 66(1):207-18. https://doi.org/10.1007/s12026-017-8973-4.

27. Khosravi M, Karimi MH, Hossein Aghdaie M, Kalani M, Naserian S, Bidmeshkipour A. Mesenchymal stem cells can induce regulatory T cells via modulating miR-126a but not miR-10a. Gene. 2017;627:327-36. https://doi. org/10.1016/j.gene.2017.06.012

28. Faustman DL, Davis M. TNF receptor 2 and disease: autoimmunity and regenerative medicine. Front Immunol. 2013;4:478. https://doi.org/10.3389/ fimmu.2013.00478

29. Yang S, Wang J, Brand DD, Zheng SG. Role of TNF-TNF receptor 2 signal in regulatory T cells and its therapeutic implications. Front Immunol. 2018;9: 784. https://doi.org/10.3389/fimmu.2018.00784.

30. Tan J, Weil BR, Abarbanell AM, et al. Ablation of TNF-alpha receptors influences mesenchymal stem cell-mediated cardiac protection against ischemia. Shock Augusta Ga. 2010;34(3):236-42. https://doi.org/10.1097/SHK. ob013e3181d75ae3.

31. Kelly ML, Wang M, Crisostomo PR, et al. TNF receptor 2, not TNF receptor 1 , enhances mesenchymal stem cell-mediated cardiac protection following acute ischemia. Shock Augusta Ga. 2010;33(6):602-7. https://doi.org/10. 1097/SHK.0b013e3181cc0913.

32. Zhang A, Wang Y, Ye Z, Xie H, Zhou L, Zheng S. Mechanism of TNF-ainduced migration and hepatocyte growth factor production in human mesenchymal stem cells. J Cell Biochem. 2010;111(2):469-75. https://doi. org/10.1002/jcb.22729

33. Crisostomo PR, Wang Y, Markel TA, Wang M, Lahm T, Meldrum DR. Human mesenchymal stem cells stimulated by TNF-alpha, LPS, or hypoxia produce growth factors by an NF kappa B- but not JNK-dependent mechanism. Am J Physiol Cell Physiol. 2008;294(3):C675-82. https://doi.org/10.1152/ajpcell. 00437.2007.

34. Park N, Rim YA, Jung $H$, et al. Etanercept-synthesising mesenchymal stem cells efficiently ameliorate collagen-induced arthritis. Sci Rep. 2017;7:39593. https://doi.org/10.1038/srep39593.

35. Liu LN, Wang G, Hendricks K, et al. Comparison of drug and cell-based delivery: engineered adult mesenchymal stem cells expressing soluble tumor necrosis factor receptor II prevent arthritis in mouse and rat animal models. Stem Cells Transl Med. 2013;2(5):362-75. https://doi.org/10.5966/ sctm.2012-0135.

36. Bao C, Guo J, Lin G, Hu M, Hu Z. TNFR gene-modified mesenchymal stem cells attenuate inflammation and cardiac dysfunction following MI. Scand Cardiovasc J SCJ. 2008;42(1):56-62. https://doi.org/10.1080/ 14017430701543556

37. Bao C, Guo J, Zheng M, Chen Y, Lin G, Hu M. Enhancement of the survival of engrafted mesenchymal stem cells in the ischemic heart by TNFR gene transfection. Biochem Cell Biol Biochim Biol Cell. 2010;88(4):629-34. https:// doi.org/10.1139/010-018

38. Leclerc M, Naserian S, Pilon C, et al. Control of GVHD by regulatory T cells depends on TNF produced by T cells and TNFR2 expressed by regulatory T cells. Blood. 2016;128(12):1651-9. https://doi.org/10.1182/blood-2016-02700849.

39. Polz J, Remke A, Weber $\mathrm{S}$, et al. Myeloid suppressor cells require membrane TNFR2 expression for suppressive activity. Immun Inflamm Dis. 2014;2(2): 121-30. https://doi.org/10.1002/iid3.19.

40. Ticha $\mathrm{O}$, Moos L, Wajant H, Bekeredjian-Ding I. Expression of tumor necrosis factor receptor 2 characterizes TLR9-driven formation of interleukin-10producing B cells. Front Immunol. 2017;8:1951. https://doi.org/10.3389/ fimmu.2017.01951.

41. Naserian S, Abdelgawad ME, Afshar Bakshloo M, et al. The TNF/TNFR2 signaling pathway is a key regulatory factor in endothelial progenitor cell immunosuppressive effect. Cell Commun Signal CCS. 2020;18(1):94. https:// doi.org/10.1186/s12964-020-00564-3.

42. Papadopoulou A, Yiangou M, Athanasiou E, et al. Mesenchymal stem cells are conditionally therapeutic in preclinical models of rheumatoid arthritis. Ann Rheum Dis. 2012;71(10):1733-40. https://doi.org/10.1136/annrheumdis2011-200985 
43. Sheng $H$, Wang $Y$, Jin $Y$, et al. A critical role of IFNY in priming MSCmediated suppression of $\mathrm{T}$ cell proliferation through up-regulation of B7-H1. Cell Res. 2008;18(8):846-57. https://doi.org/10.1038/cr.2008.80.

44. Polchert D, Sobinsky J, Douglas G, et al. IFN- $\gamma$ activation of mesenchyma stem cells for treatment and prevention of graft versus host disease. Eur J Immunol. 2008;38(6):1745-55. https://doi.org/10.1002/eji.200738129.

45. Ma OK-F, Chan KH. Immunomodulation by mesenchymal stem cells: interplay between mesenchymal stem cells and regulatory lymphocytes. World J Stem Cells. 2016;8(9):268-78. https://doi.org/10.4252/wjsc.v8.i9.268.

46. Croft M, Siegel RM. Beyond TNF: TNF superfamily cytokines as targets for the treatment of rheumatic diseases. Nat Rev Rheumatol. 2017;13(4):217-33. https://doi.org/10.1038/nrrheum.2017.22

47. Redondo-Castro E, Cunningham C, Miller J, et al. Interleukin-1 primes human mesenchymal stem cells towards an anti-inflammatory and protrophic phenotype in vitro. Stem Cell Res Ther. 2017;8(1):79. https://doi.org/ 10.1186/s13287-017-0531-4

48. Doucet $C$, Ernou I, Zhang Y, et al. Platelet lysates promote mesenchymal stem cell expansion: a safety substitute for animal serum in cell-based therapy applications 2005;236(January):228-236. doi:https://doi.org/10.1002/jcp.20391.

49. Reddy M, Eirikis E, Davis C, Davis HM, Prabhakar U. Comparative analysis of lymphocyte activation marker expression and cytokine secretion profile in stimulated human peripheral blood mononuclear cell cultures: an in vitro model to monitor cellular immune function. J Immunol Methods. 2004; 293(1-2):127-42. https://doi.org/10.1016/j.jim.2004.07.006.

50. Chen X, Hamano R, Subleski JJ, Hurwitz AA, Howard OMZ, Oppenheim JJ. Expression of costimulatory TNFR2 induces resistance of CD4+FoxP3conventional T cells to suppression by CD4+FoxP3+ regulatory T cells. J Immunol Baltim Md 1950. 2010;185(1):174-82. https://doi.org/10.4049/ jimmunol.0903548.

51. Dong $C$, Juedes $A E$, Temann UA, et al. ICOS co-stimulatory receptor is essential for T-cell activation and function. Nature. 2001;409(6816):97-101. https://doi.org/10.1038/35051100.

52. Pierini A, Strober W, Moffett C, et al. TNF-a priming enhances CD4+FoxP3+ regulatory T-cell suppressive function in murine GVHD prevention and treatment. Blood. 2016;128(6):866-71. https://doi.org/10.1182/blood-201604-711275.

53. Wu Y, Chen L, Scott PG, Tredget EE. Mesenchymal stem cells enhance wound healing through differentiation and angiogenesis. Stem Cells Dayt Ohio. 2007;25(10):2648-59. https://doi.org/10.1634/stemcells.2007-0226.

54. Lukomska B, Stanaszek L, Zuba-Surma E, Legosz P, Sarzynska S, Drela K. Challenges and controversies in human mesenchymal stem cell therapy. Stem Cells Int. 2019:2019:9628536. https://doi.org/10.1155/2019/9628536.

55. Galipeau J, Sensébé L. Mesenchymal stromal cells: clinical challenges and therapeutic opportunities. Cell Stem Cell. 2018;22(6):824-33. https://doi.org/ 10.1016/j.stem.2018.05.004

56. Putra A, Ridwan FB, Putridewi Al, et al. The role of TNF-a induced MSCs on suppressive inflammation by increasing TGF- $\beta$ and IL-10. Open Access Maced J Med Sci. 2018;6(10):1779-83. https://doi.org/10.3889/oamjms.2018.404

57. Song W-J, Li Q, Ryu M-O, et al. Canine adipose tissue-derived mesenchymal stem cells pre-treated with TNF-alpha enhance immunomodulatory effects in inflammatory bowel disease in mice. Res Vet Sci. 2019;125:176-84. https://doi.org/10.1016/j.rvsc.2019.06.012.

58. Chen $H_{1}$ Min $X-H$, Wang $\mathrm{Q}-\mathrm{Y}$, et al. Pre-activation of mesenchymal stem cells with TNF- $a, I L-1 \beta$ and nitric oxide enhances its paracrine effects on radiation-induced intestinal injury. Sci Rep. 2015;5:8718. https://doi.org/10. 1038/srep08718

59. Hu X, Li B, Li X, et al. Transmembrane TNF-a promotes suppressive activities of myeloid-derived suppressor cells via TNFR2. J Immunol Baltim Md 1950 2014;192(3):1320-31. https://doi.org/10.4049/jimmunol.1203195.

60. Kuno R, Wang J, Kawanokuchi J, Takeuchi H, Mizuno T, Suzumura A. Autocrine activation of microglia by tumor necrosis factor-alpha. J Neuroimmunol. 2005; 162(1-2):89-96. https://doi.org/10.1016/j.jneuroim.2005.01.015.

61. Naudé PJW, den Boer JA, Luiten PGM, Eisel ULM. Tumor necrosis factor receptor cross-talk. FEBS J. 2011;278(6):888-98. https://doi.org/10.1111/j. 1742-4658.2011.08017.x.

62. Lubrano di Ricco M, Ronin E, Collares D, et al. Tumor necrosis factor receptor family costimulation increases regulatory T-cell activation and function via NFkB. Eur J Immunol. 2020. https://doi.org/10.1002/eji.201948393.

63. Ronin E, Lubrano di Ricco M, Vallion R, et al. The NF-KB RelA transcription factor is critical for regulatory $T$ cell activation and stability. Front Immunol. 2019;10:2487. https://doi.org/10.3389/fimmu.2019.02487.
64. Chen X, Subleski JJ, Kopf H, Howard OMZ, Männel DN, Oppenheim JJ. Cutting edge: expression of TNFR2 defines a maximally suppressive subset of mouse CD4+CD25+FoxP3+ T regulatory cells: applicability to tumorinfiltrating T regulatory cells. J Immunol Baltim Md 1950. 2008;180(10):646771. https://doi.org/10.4049/jimmunol.180.10.6467.

65. He X, Landman S, Bauland SCG, van den Dolder J, Koenen HJPM, Joosten I. A TNFR2-agonist facilitates high purity expansion of human low purity Treg cells. PLoS One. 2016;11(5):e0156311. https://doi.org/10.1371/journal.pone.0156311.

66. Chang Al, Schwertschkow AH, Nolta JA, Wu J. Involvement of mesenchymal stem cells in cancer progression and metastases. Curr Cancer Drug Targets. 2015;15(2):88-98. https://doi.org/10.2174/1568009615666150126154151.

67. Hill BS, Pelagalli A, Passaro N, Zannetti A. Tumor-educated mesenchymal stem cells promote pro-metastatic phenotype. Oncotarget. 2017;8(42): 73296-311. https://doi.org/10.18632/oncotarget.20265.

68. Pietrovito L, Leo A, Gori V, et al. Bone marrow-derived mesenchymal stem cells promote invasiveness and transendothelial migration of osteosarcoma cells via a mesenchymal to amoeboid transition. Mol Oncol. 2018;12(5):65976. https://doi.org/10.1002/1878-0261.12189.

69. Naserian S, Leclerc M, Thiolat A, et al. Simple, reproducible, and efficient clinical grading system for murine models of acute graft-versus-host disease. Front Immunol. 2018;9:10. https://doi.org/10.3389/fimmu.2018.00010.

70. Naserian S, Abdelgawad ME, Lachaux J, et al. Development of bio-artificial micro-vessels with immunosuppressive capacities: a hope for future transplantations and organoids. Blood. 2019:134(Supplement 1):3610. https://doi.org/10.1182/blood-2019-121395.

71. Torrey H, Butterworth J, Mera T, et al. Targeting TNFR2 with antagonistic antibodies inhibits proliferation of ovarian cancer cells and tumor-associated Tregs. Sci Signal. 2017;10(462). https://doi.org/10.1126/scisignal.aaf8608.

72. Torrey H, Khodadoust M, Tran L, et al. Targeted killing of TNFR2-expressing tumor cells and Tregs by TNFR2 antagonistic antibodies in advanced Sézary syndrome. Leukemia. 2019;33(5):1206-18. https://doi.org/10.1038/s41375018-0292-9

73. Goukassian DA, Qin G, Dolan C, et al. Tumor necrosis factor-alpha receptor p75 is required in ischemia-induced neovascularization. Circulation. 2007; 115(6):752-62. https://doi.org/10.1161/CIRCULATIONAHA.106.647255.

\section{Publisher's Note}

Springer Nature remains neutral with regard to jurisdictional claims in published maps and institutional affiliations.

Ready to submit your research? Choose BMC and benefit from:

- fast, convenient online submission

- thorough peer review by experienced researchers in your field

- rapid publication on acceptance

- support for research data, including large and complex data types

- gold Open Access which fosters wider collaboration and increased citations

- maximum visibility for your research: over $100 \mathrm{M}$ website views per year

At BMC, research is always in progress.

Learn more biomedcentral.com/submissions 